\title{
Interaction of the Cell Adhesion Molecule CHL1 with Vitronectin, Integrins, and the Plasminogen Activator Inhibitor-2 Promotes CHL1-Induced Neurite Outgrowth and Neuronal Migration
}

\author{
Jelena Katic, ${ }^{1 *}$ Gabriele Loers, ${ }^{1 *}$ Ralf Kleene, ${ }^{1 *}$ Nicole Karl, ${ }^{1 \star}$ Carsten Schmidt, ${ }^{1}$ Friedrich Buck, ${ }^{2}$ \\ Jaroslaw W. Zmijewski, ${ }^{6}$ Igor Jakovcevski, ${ }^{1}$ Klaus T. Preissner, ${ }^{3}$ and Melitta Schachner ${ }^{4,5}$ \\ ${ }^{1}$ Zentrum für Molekulare Neurobiologie, and ${ }^{2}$ Institut für Klinische Chemie, Universitätsklinikum Hamburg-Eppendorf, 20246 Hamburg, Germany, \\ ${ }^{3}$ Department of Biochemistry, Medical School, Justus-Liebig-University, 35392 Giessen, Germany, ${ }^{4}$ Keck Center for Collaborative Neuroscience and \\ Department of Cell Biology and Neuroscience, Rutgers University, Piscataway, New Jersey 08854, ${ }^{5}$ Center for Neuroscience, Shantou University Medical \\ College, Shantou 515041, People's Republic of China, and ' Division of Pulmonary, Allergy \& Critical Care Medicine, University of Alabama at Birmingham, \\ BMRII-304, Birmingham, Alabama 35294
}

\begin{abstract}
The cell adhesion molecule close homolog of L1 (CHL1) plays important functional roles in the developing and adult nervous system. In search of the binding partners that mediate the diverse and sometimes opposing functions of CHL1, the extracellular matrix-associated proteins vitronectin and plasminogen activator inhibitor-2 (PAI-2) were identified as novel CHL1 interaction partners and tested for involvement in CHL1-dependent functions during mouse cerebellar development. CHL1-induced cerebellar neurite outgrowth and cell migration at postnatal days 6 - 8 were inhibited by a CHL1-derived peptide comprising the integrin binding RGD motif, and by antibodies against vitronectin or several integrins, indicating a vitronectin-dependent integrin-mediated pathway. A PAI-2-derived peptide, or antibodies against PAI-2, urokinase type plasminogen activator (uPA), uPA receptor, and several integrins reduced cell migration. CHL1 colocalized with vitronectin, PAI-2, and several integrins in cerebellar granule cells, suggesting an association among these proteins. Interestingly, at the slightly earlier age of 4-5 d, cerebellar neurons did not depend on CHL1 for neuritogenesis and cell migration. However, differentiation of progenitor cells into neurons at this stage was dependent on homophilic CHL1-CHL1 interactions. These observations indicate that homophilic CHL1 trans-interactions regulate differentiation of neuronal progenitor cells at early postnatal stages, while heterophilic trans-interactions of CHL1 with vitronectin, integrins, and the plasminogen activator system regulate neuritogenesis and neuronal cell migration at a later postnatal stage of cerebellar morphogenesis. Thus, within very narrow time windows in postnatal cerebellar development, distinct types of molecular interactions mediated by CHL1 underlie the diverse functions of this protein.
\end{abstract}

Key words: cerebellar development; CHL1; integrins; migration; plasminogen system; vitronectin

\section{Introduction}

Cell adhesion molecule close homolog of L1 (CHL1) is important for neural cell proliferation, migration, differentiation, and sur-

\footnotetext{
Received Aug. 1, 2013; revised Aug. 28, 2014; accepted Sept. 3, 2014.

Author contributions: G.L., R.K., N.K., and C.S. designed research;J.K., G.L., R.K., N.K., C.S., F.B., and I.J. performed research; J.W.Z. and K.T.P. contributed unpublished reagents/analytic tools; J.K., G.L., R.K., N.K., F.B., and I.J. analyzed data; R.K. and M.S. wrote the paper.

M.S. is supported by the New Jersey Commission for Spinal Cord Research and the Li Ka-Shing Foundation at Shantou University Medical College. We thank Eva Kronberg for excellent animal care; Ute Bork and Emanuela Szpotowicz for excellent technical assistance; Stephan Kaizik for performing preliminary experiments; Dominique Belin for the plasminogen activator inhibitor-2 (PAl-2)-coding plasmid; and Shaoning Jiang for helping with tissue preparation from vitronectin-deficient mice.

*J.K., G.L., R.K., and N.K. contributed equally to this work.

The authors declare no competing financial interests.

Correspondence should be addressed to Melitta Schachner, W. M. Keck Center for Collaborative Neuroscience and Department of Cell Biology and Neuroscience, Rutgers University, 604 Allison Road, Piscataway, NJ 08854. E-mail: schachner@biology.rutgers.edu.

DOI:10.1523/JNEUROSCI.3280-13.2014

Copyright $\odot 2014$ the authors $\quad 0270-6474 / 14 / 3414606-18 \$ 15.00 / 0$
}

vival, as well as in neuritogenesis, synaptogenesis, synaptic plasticity, and regeneration after injury (Holm et al., 1996; Hillenbrand et al., 1999; Jakovcevski et al., 2007; Loers and Schachner, 2007; Maness and Schachner, 2007). In humans, CHL1 is linked to mental retardation, schizophrenia, major depression, epilepsy, and autism spectrum disorders (Angeloni et al., 1999a,b; Sakurai et al., 2002; Frints et al., 2003; Chen et al., 2005; Chu and Liu, 2010; Tam et al., 2010; Cuoco et al., 2011; Morag et al., 2011; Salyakina et al., 2011; Shoukier et al., 2013). CHL1-deficient mice show alterations in social and exploratory behavior, reactivity to novelty, ability to gate sensorimotor information, and working memory (Montag-Sallaz et al., 2002; Pratte et al., 2003; Irintchev et al., 2004; Morellini et al., 2007; Kolata et al., 2008; Pratte and Jamon, 2009). Morphological alterations and synaptic dysfunctions have been observed in the hippocampus, olfactory bulb, and cortex (Montag-Sallaz et al., 2002; Demyanenko et al., 2004, 2011; Leshchyns'ka et al., 2006; Nikonenko et 
al., 2006; Wright et al., 2007; Andreyeva et al., 2010). In the cerebellum of constitutively CHL1-deficient mice, increased numbers of migrating cells were observed at the end of the first postnatal week, while a loss of Purkinje and granule cells was observed in adult mice (Jakovcevski et al., 2009), indicating that CHL1 plays a role not only in early postnatal mouse cerebellar development, but also in the adult.

To understand the mechanisms underlying the diverse CHL1 functions, in vitro studies were performed, yielding results that did not easily fit into a coherent concept of CHL1 functions in vivo. Function-triggering CHL1 antibodies enhanced neuritogenesis (Chen et al., 1999), whereas homophilic CHL1 interactions studied with cells from constitutively CHL1-deficient mice showed that CHL1 is inhibitory for neuritogenesis in vitro and in vivo: CHL1-deficient mice recover better after spinal cord injury than their wild-type littermates, CHL1-deficient neurons grow better on CHL1-expressing astrocytes than wild-type neurons, and CHL1-expressing neurons grow better on CHL1-negative astrocytes (Jakovcevski et al., 2007). These observations led to the conclusion that homophilic (CHL1-CHL1) interactions block the neurite outgrowth-promoting functions of CHL1, whereas heterophilic CHL1 interactions with, for instance, integrins in cis- and trans-configurations are conducive (Hillenbrand et al., 1999; Buhusi et al., 2003; Demyanenko et al., 2004; Jakovcevski et al., 2007, 2009).

The present study therefore had the aim to search for novel interaction partners of CHL1 that would extend the current knowledge on the molecular mechanisms underlying CHL1 functions. Here, we show that the interaction of vitronectin with the extracellular domain of CHL1 induces integrin-mediated neuritogenesis; whereas interactions of CHL1 with vitronectin, plasminogen activator inhibitor-2 (PAI-2), urokinase type plasminogen activator (uPA), uPA receptor (uPAR), or $\alpha \mathrm{v}, \alpha 1, \alpha 2$, $\alpha 3, \beta 1$, and $\beta 3$ integrins, but not other integrin heterodimers, enhance cerebellar granule cell migration, suggesting that vitronectin and its diverse interaction partners play a crucial role in determining the functions of CHL1.

\section{Materials and Methods}

Animals. Male and female CHL1-deficient $\left(\mathrm{CHL}^{-1-}\right.$; Montag-Sallaz et al., 2002) and male L1-deficient (L1 ${ }^{-/ y}$; Dahme et al., 1997) mice, which both had been back-crossed onto the C57BL/6J background for more than eight generations, and their age-matched wild-type $\left(\mathrm{CHL}^{+/+}\right.$and $\mathrm{L} 1^{+/ \mathrm{y}}$ ) male and female littermates as well as C57BL/6J wild-type mice of either sex and male vitronectin-deficient $\left(\mathrm{VN}^{-/-}\right)$mice (Bae et al., 2013) were used. All animal experiments were approved by the local authorities of the State of Hamburg (animal permits ORG 535 and G09/098) and conform to the guidelines set by the European Union.

Antibodies and reagents. Polyclonal antibodies against the extracellular domain of CHL1 or L1 were as described previously (Chen et al., 1999; Rolf et al., 2003), and a polyclonal goat antibody against intracellular CHL1 epitopes was from R\&D Systems. Polyclonal antibodies against vitronectin were from Santa Cruz Biotechnology (Table 1) or were raised as described previously (Preissner et al., 1989). Antibodies against the different integrin subunits, vitronectin, PAI-1, PAI-2, uPA, or uPAR were from different sources (Table 1). Mouse $\beta$ III-tubulin antibody was from Covance, goat doublecortin antibody was from Santa Cruz Biotechnology, rabbit Pax6 and mouse NeuN antibodies were from Millipore, and rabbit Ki67 antibody was from Abcam. CHL1-Fc, L1-Fc, NCAM-Fc, and APP-Fc, comprising the extracellular domains of these murine molecules in fusion with the Fc portion of human IgG, have been described previously (Chen et al., 1999; Schmidt et al., 2008). Purification of vitronectin has also been described (Preissner et al., 1985). Horseradish peroxidase (HRP)-coupled and fluorescent dyecoupled secondary antibodies were from Jackson ImmunoResearch. Re-
Table 1. Antibodies used in this study

\begin{tabular}{|c|c|c|c|c|}
\hline Subunit/antigen & Name & Species & Company & $\begin{array}{l}\text { Catalog } \\
\text { number }\end{array}$ \\
\hline Integrin $\alpha 1$ & $\alpha 1-b$ & Hamster & BioLegend & 142601 \\
\hline Integrin $\alpha 2$ & $\alpha 2$ & Hamster & BioLegend & 103507 \\
\hline Integrin $\alpha 4$ & $\alpha 4$ & Rat & BioLegend & 103707 \\
\hline Integrin $\alpha 5$ & $\alpha 5$ & Rat & BioLegend & 103807 \\
\hline Integrin $\alpha 6$ & $\alpha 6$ & Rat & BioLegend & 313613 \\
\hline Integrin $\alpha v$ & $\alpha v-b$ & Rat & BioLegend & 104107 \\
\hline Integrin $\beta 1$ & $\beta 1-b$ & Hamster & BioLegend & 102209 \\
\hline Integrin $\beta 2$ & $\beta 2$ & Rat & BioLegend & 101409 \\
\hline Integrin $\beta 3$ & $\beta 3-b$ & Hamster & BioLegend & 104309 \\
\hline Integrin $\alpha$ v & $\alpha v-C$ & Goat & Santa Cruz Biotechnology & sc-6617 \\
\hline Integrin $\alpha v$ & $\alpha v-N$ & Goat & Santa Cruz Biotechnology & sc-6616 \\
\hline Integrin $\alpha 1$ & $\alpha 1-\mathrm{N}$ & Mouse & Millipore & MAB1973Z \\
\hline Integrin $\alpha 3$ & $\alpha 3$ & Goat & Santa Cruz Biotechnology & sc- 6588 \\
\hline Integrin $\alpha 7$ & $\alpha 7$ & Goat & Santa Cruz Biotechnology & sc- 27706 \\
\hline Integrin $\beta 1$ & $\beta 1-s c$ & Goat & Santa Cruz Biotechnology & sc- 6622 \\
\hline Integrin $\beta 3$ & $\beta 3-s c$ & Goat & Santa Cruz Biotechnology & sc-6626 \\
\hline Integrin $\beta 1$ & $\beta 1-C 1$ & Rat & Chemicon & ab1997 \\
\hline Integrin $\beta 1$ & $\beta 1-C 2$ & Rabbit & Chemicon & ab1952 \\
\hline Integrin $\beta 1$ & $\beta 1-A F$ & Goat & R\&D Systems & AF2405 \\
\hline $\begin{array}{l}\text { Vitronectin (amino acids } \\
\text { 1-270) }\end{array}$ & Vitronectin & Rabbit & Santa Cruz Biotechnology & sc-15332 \\
\hline PAI-2 (amino acids 61-130) & rb-PAl-2 & Rabbit & Santa Cruz Biotechnology & sc-25746 \\
\hline PAI-1 (amino acids 24-158) & rb-PAl-1 & Rabbit & Santa Cruz Biotechnology & sc-8979 \\
\hline PAI-2 (N terminal) & gt-PAl-2 & Goat & Santa Cruz Biotechnology & sc- 6649 \\
\hline PAI-1 (C terminal) & gt-PAl-1 & Goat & Santa Cruz Biotechnology & sc-6642 \\
\hline uPA (amino acids 136-275) & UPA & Rabbit & Santa Cruz Biotechnology & sc-14019 \\
\hline uPAR (amino acids 1-290) & UPAR & Rabbit & Santa Cruz Biotechnology & sc-10815 \\
\hline
\end{tabular}

combinant PAI-2, human Fc, streptavidin-HRP, or neutravidin-HRP were from Sigma-Aldrich.

The synthetic peptides RGD (ERVYMSQRGDLYFANVEE) and DGEA (KLSWSKDGEAFEMNGTED) comprising amino acids 178-195 and 549-566 of mouse CHL1, respectively, and their mutated versions KGE (ERVYMSQKGELYFANVEE) and AGEV (KLSWSKAGEVFEM NGTED), respectively, as well as the PAI-2 peptide (KGKANFSGM SERNDL) comprising amino acids $334-353$ of mouse PAI-2 or its scrambled version (MRADFEGNSNGKSLK) were from Schafer-N.

The cDNA coding for a recombinant $\mathrm{N}$-terminal vitronectin fragment comprising amino acids 1-203 was amplified by PCR from a mouse brain cDNA library. The cDNA coding for the recombinant $\mathrm{N}$ - or C-terminal PAI-2 fragments comprising amino acids $1-200$ or 160-415 was amplified from a plasmid coding for full-length PAI-2 (a gift from Dominique Belin, Département de Pathologie and Immunologie, Centre Médical Universitaire, Geneva, Switzerland). The cDNAs were cloned into pQE30 via a BamHI restriction site using the InFusion Cloning Kit (Clontech). Production of the His-tagged recombinant fragments was performed according to the manufacturer's instructions.

Biochemical cross-linking and preparation of brain homogenate and a synaptosomal fraction. Preparation of brain homogenate and of a synaptosomal fraction from 2- to 3-month-old C57BL/6J mice (Schmidt et al., 2008; Makhina et al., 2009) and cross-linking were performed as described previously (Schmidt et al., 2008). Briefly, the trifunctional crosslinker sulfo-SBED (Thermo Fisher Scientific) was conjugated to CHL1-Fc or APP-Fc, followed by binding to protein A-coupled magnetic beads (Dynabeads, Invitrogen). The beads were washed to remove excess cross-linker and incubated with a synaptosomal fraction isolated from adult mouse brains. The samples were then exposed to UV light, and bound proteins were eluted by boiling the beads in SDS sample buffer ( 80 mм Tris/HCl, pH 6.8, 10\% glycerol, $1 \%$ SDS; $1 \%$ dithiothreitol).

Mass spectrometry. Nano-electrospray mass spectrometry of excised silver-stained bands was performed as described previously (Kleene et al., 2007; Schmidt et al., 2008; Makhina et al., 2009).

ELISA, label-free binding assay, and bead aggregation assay. ELISA and label-free binding assay have been described (Schmidt et al., 2008; 
Makhina et al., 2009; Loers et al., 2012). For quantitative assessment of the CHL1 and vitronectin interaction, a bead aggregation assay was performed (Jakovcevski et al., 2007). Briefly, a $10 \mu \mathrm{l}$ suspension of protein A-coupled magnetic beads (Dynabeads, Invitrogen) was incubated in PBS, pH 7.4, overnight at $4^{\circ} \mathrm{C}$ with $37.5 \mathrm{~nm}$ CHL1-Fc, L1-Fc, or NCAMFc. After washing, the beads were resuspended in PBS, sonicated in ice-cold water, collected by centrifugation, and resuspended in PBS containing $0.1 \mathrm{mg} / \mathrm{ml} \mathrm{BSA}$ in the absence or presence of $600 \mu \mathrm{g} / \mathrm{ml}$ vitronectin. The resuspended beads were incubated at room temperature, and bead aggregation was analyzed using a Zeiss Axiovert microscope and AxioVision software 4.6 (Carl Zeiss). The diameters of the aggregates were determined and used to estimate the number of beads per aggregate (Jakovcevski et al., 2007). The aggregates were categorized into the following three groups: aggregates with $<10$, with $10-1000$, and with $>1000$ beads. The number of aggregates relative to all beads in all samples was calculated.

Neurite outgrowth and migration of cerebellar granule cells. Monolayer cultures of dissociated cerebellar cells were prepared from 4- to 5-d-old or 6- to 8-d-old mice, as described previously (Makhina et al., 2009). For neurite outgrowth assays, single-cell suspensions $\left(1-2 \times 10^{5}\right.$ cells $\left./ \mathrm{ml}\right)$ were seeded onto coverslips precoated with $100 \mu \mathrm{g} / \mathrm{ml}$ poly-L-lysine (PLL; Sigma-Aldrich) with or without $10 \mu \mathrm{g} / \mathrm{ml}$ CHL1-Fc. After fixation with $2.5 \%$ glutaraldehyde, neurons were stained with toluidine blue and methylene blue, and neurite outgrowth was quantified by measuring total neurite lengths of at least 100 neurons per condition using the AxioVision imaging system 4.6 (Carl Zeiss). Migration of granule cells was measured in explant cultures from 4- to 5-d-old or 6- to 8-d-old mice, as described previously (Kalus et al., 2003). Briefly, cerebella were passed through a Nitrex net with a pore width of $300 \mu \mathrm{m}$, and the tissue pieces were plated onto PLL-coated coverslips with or without CHL1-Fc and maintained in serum-containing culture medium for $24 \mathrm{~h}$. Afterward, the explants were transferred into serum-free medium, cultured for an additional $24 \mathrm{~h}$, then fixed with $2.5 \%$ glutaraldehyde, and stained with toluidine blue and methylene blue. Cell migration was quantitated by measuring the number of cell bodies in defined distance intervals of 10 explants per condition and an experiment using the AxioVision imaging system 4.6 (Carl Zeiss). Antibodies, peptides, and recombinant proteins were applied at final concentrations of 5, 100, and $10 \mu \mathrm{g} / \mathrm{ml}$, respectively.

Phage display. The Ph.D.-12 Phage Display Peptide Library (New England BioLabs) displaying $10^{8}-10^{10}$ random 12 -mer peptides at the pili of M13-like phage particles in fusion with the N-terminus of the pVIII major coat protein and CHL1-Fc were used for the screening of peptides binding to the extracellular domain of CHL1. All selection steps were performed according to the Ph.D.-12 Phage Display Peptide Library Kit instruction manual version 2.0 (New England BioLabs; Wang et al., 2011).

Western blot analysis, immunoprecipitation, and pull-down assay. Western blot analysis, immunoprecipitation and pull-down assay have been described in detail (Schmidt et al., 2008; Makhina et al., 2009).

Immunocytochemistry. Live dissociated cerebellar neurons in monolayer culture were incubated with $500 \mu \mathrm{l}$ culture medium containing 15 $\mu \mathrm{g} / \mathrm{ml} \mathrm{CHL1-Fc} \mathrm{or} \mathrm{Fc} \mathrm{for} 20 \mathrm{~min}$ at $37^{\circ} \mathrm{C}$. After fixation with $4 \%$ paraformaldehyde in HBSS for $15 \mathrm{~min}$, cells were incubated for $30 \mathrm{~min}$ with $3 \%$ BSA in PBS followed by incubation with primary antibodies for $1 \mathrm{~h}$ at room temperature, washing with PBS, and incubation with secondary antibodies coupled to fluorescent dyes for $1 \mathrm{~h}$ at room temperature in the dark. Bovine or donkey Cy3-conjugated antibodies directed against goat IgGs; donkey or goat Cy2-conjugated antibodies directed against mouse IgGs; and donkey or goat Cy5-, or Alexa Fluor 647-conjugated antibodies directed against human Fc were used. For permeabilization, fixed cells were washed twice with PBS and incubated with 3\% BSA/0.1\% Triton $\mathrm{X}-100$ in PBS at room temperature for $1 \mathrm{~h}$. Coverslips were embedded in Aqua-Polymount (Polysciences). Confocal images were taken with an Olympus Fluoview FV1000 confocal laser-scanning microscope.

For identification of undifferentiated granule cell precursors, dissociated cerebellar cells were fixed, permeabilized, and stained with $\beta$ IIItubulin antibody and DAPI. Ten images per condition were taken $(20 \times$ objective). Total cell numbers were determined by counting DAPIpositive cells, and numbers of undifferentiated cells were determined by counting $\beta$ III-tubulin-negative cells identified by their round, dark blue nucleus.

Tissue preparation, immunohistochemistry, and proximity ligation assay. Mice were killed at postnatal days 3, 5 and 7, and their brains were immersed in $4 \%$ formaldehyde solution in $0.1 \mathrm{M}$ cacodylate buffer, $\mathrm{pH}$ 7.3, as described previously (Jakovcevski et al., 2009). The brains were postfixed overnight at $4^{\circ} \mathrm{C}$ in the formaldehyde solution, immersed into a $15 \%$ sucrose solution in the same buffer for $2 \mathrm{~d}$ at $4^{\circ} \mathrm{C}$, frozen by immersion for 2 min into 2-methyl-butane (isopentane) precooled to $-80^{\circ} \mathrm{C}$, and stored in liquid nitrogen until sectioned. Serial coronal 25$\mu \mathrm{m}$-thick sections of the whole cerebellum were cut in a cryostat (Leica CM3050, Leica Instruments) and collected on SuperFrost Plus glass slides (Carl Roth). Antigen retrieval was performed by incubating the sections in $10 \mathrm{~mm}$ sodium citrate solution, $\mathrm{pH} 9.0$, for $30 \mathrm{~min}$ in a water bath at $80^{\circ} \mathrm{C}$, followed by blocking of nonspecific binding sites with PBS containing $0.2 \%$ Triton X-100 (Sigma), $0.02 \%$ sodium azide (Merck), and 5\% normal donkey serum (Jackson ImmunoResearch) for $1 \mathrm{~h}$ at room temperature. The sections were incubated with rabbit Ki67 antibody, mouse NeuN antibody, and rabbit Pax6 antibody, with a mixture of goat CHL1 antibody with either rabbit vitronectin or rabbit PAI-2 antibody and with a mixture of rabbit Pax6 antibody with either goat doublecortin or mouse NeuN antibody, overnight at $4^{\circ} \mathrm{C}$ in a humid chamber. All primary antibodies were used at optimal dilutions in PBS. Following washing in PBS ( $3 \times 15 \mathrm{~min}$ at room temperature), the sections were incubated with a donkey $\mathrm{Cy} 3$-conjugated anti-mouse antibody, donkey Cy3-conjugated anti-rabbit antibody, a mixture of donkey Cy3-conjugated anti-goat and Cy2-conjugated anti-rabbit antibodies, or a mixture of donkey Cy3-conjugated anti-rabbit antibody with either donkey Cy2-conjugated anti-goat or anti-mouse antibody for $2 \mathrm{~h}$ at room temperature. All secondary antibodies were diluted 1:200 in PBS. After a subsequent wash in PBS, cell nuclei were stained for $10 \mathrm{~min}$ at room temperature with bis-benzimide solution (Hoechst dye 33258, 5 $\mu \mathrm{g} / \mathrm{ml}$ in PBS, Sigma). Finally, the sections were washed again, mounted with Fluoromount $\mathrm{G}$ (Southern Biotechnology Associates), and stored at $4^{\circ} \mathrm{C}$ in the dark. Microphotographs were taken either with a Leica confocal laser-scanning microscope (Leica) at a digital resolution $1024 \times$ 1024 and $40 \times$ objective or with an Olympus Fluoview FV1000 confocal laser-scanning microscope in sequential mode with a $60 \times$ objective. Photographs were further processed by using Photoshop CS5 software (Adobe Systems) to adjust brightness and contrast.

For proximity ligation, the sections were incubated with a mixture of goat CHL1 antibody and rabbit vitronectin or rabbit PAI-2 antibody after antigen retrieval, as described above, and blocking of nonspecific binding sites with Duolink blocking buffer (Sigma-Aldrich) for $1 \mathrm{~h}$ at room temperature. After three washes with Duolink washing buffer A (Sigma-Aldrich), a pair of secondary antibodies conjugated with oligonucleotides (Duolink anti-goat PLA probe MINUS and Duolink antirabbit PLA probe PLUS, Sigma-Aldrich) was applied to the sections, and the proximity ligation assay was performed using the Duolink detection reagents RED (Sigma-Aldrich) according to the manufacturer's protocol. Coverslips were mounted with Duolink Mounting medium with DAPI (Sigma-Aldrich), and confocal images were taken with an Olympus Fluoview FV1000 confocal laser-scanning microscope in sequential mode with a $60 \times$ objective.

Stereological analyses. Stereological analyses were performed as described in detail (Jakovcevski et al., 2009). Countings were performed on an Axio Imager.M1 microscope (Carl Zeiss) equipped with a motorized stage and Stereo Investigator 9 software-controlled computer system (MicroBrightField). Briefly, sections containing the cerebellum were observed under low-power magnification $(10 \times$ objective $)$ to delineate cerebellar layers by nuclear staining. Two cortical fields, one in the most caudal folium in the section and one in the third folium rostral to the first one, containing the cells of interest, were delineated using the Stereo Investigator software. These fields included the external granular layer, the internal granular layer, or the molecular and Purkinje cell layers, and were extended for $\sim 600 \mu \mathrm{m}$ on both sides of the sagittal plane. Four sections ( $25 \mu \mathrm{m}$; every 10 serial sections) of the cerebellar vermis were analyzed. Numerical densities were estimated by counting the nuclei of labeled cells or cells immunopositive for Ki67, NeuN, or Pax6. The pa- 
A
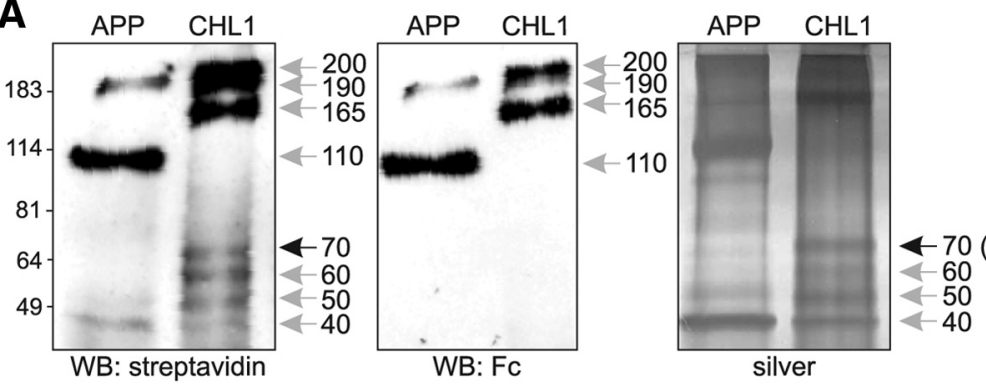

70 (VN) 50 WB: FC silver
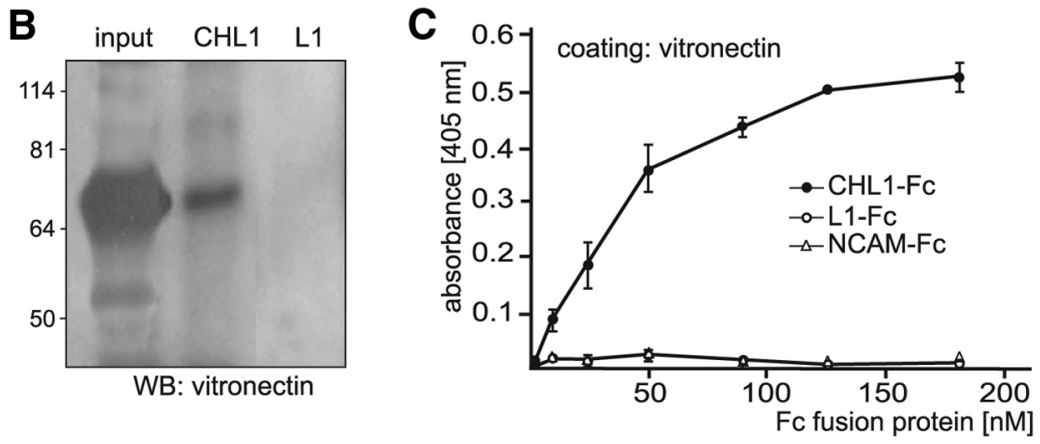

Figure 1. CHL1 interacts with vitronectin via its extracellular domain. $A$, CHL1-Fc and APP-Fc were conjugated to the crosslinker sulfo-SBED and bound to protein A magnetic beads. Beads were incubated with a synaptosomal fraction and subjected to cross-linking. Biotinylated proteins were isolated and subjected to silver staining or to Western blot (WB) analysis using HRPconjugated streptavidin or anti-human Fc antibody. Light gray arrows and numbers indicate distinct protein bands and their apparent molecular weights. The position of the $70 \mathrm{kDa}$ protein, which is identified as vitronectin (VN) is indicated by a black arrow. $\boldsymbol{B}$, CHL1-Fc and L1-Fc were incubated with brain homogenate followed by pulldown with protein A beads. Brain homogenates and precipitates were probed in Western blot analysis with vitronectin antibody. C, Substrate-coated vitronectin was incubated with increasing concentrations of soluble CHL1-Fc, L1-Fc, or NCAM-Fc, and binding was determined by ELISA using anti-human Fc antibody. Mean values \pm SD for binding from three independent experiments performed in triplicate are shown.

\section{Results}

\section{CHL1 interacts via its extracellular} domain with vitronectin

To find novel extracellular interaction partners of CHL1, a biochemical cross-linking approach was used to detect directly bound molecules. A fusion protein consisting of the extracellular domain of mouse CHL1 and human Fc (CHL1-Fc) was coupled to the trifunctional biotin-carrying crosslinker sulfo-SBED and immobilized on protein A-coupled beads. An Fc-fusion protein with the extracellular domain of the amyloid precursor protein (APP-Fc) was used as a control. A synaptosomal fraction from adult mouse brains and the immobilized conjugates were incubated and then exposed to UV light for cross-linking. Bound proteins were eluted and subjected to SDSPAGE under reducing conditions, resulting in the release of bound proteins from the CHL1-Fc and APP-Fc bait proteins and in a concomitant transfer of the biotin label from the bait proteins to the bound proteins.

By Western blot analysis using peroxidase-conjugated streptavidin, six major biotinylated proteins with apparent molecular masses of $\sim 40, \sim 50, \sim 60$, $\sim 70, \sim 165$, and $\sim 200 \mathrm{kDa}$; and three major biotinylated proteins apparent molecular masses of $\sim 40, \sim 110$, and $\sim 190 \mathrm{kDa}$ were detected in the eluates from the CHL1-Fc or APP-Fc beads, respectively

rameters for this analysis were as follows: guard space depth, $2 \mu \mathrm{m}$; base and height of the dissector, $900 \mu \mathrm{m}^{2}$ and $10 \mu \mathrm{m}$, respectively; distance between the optical dissectors, $90 \mu \mathrm{m}$; and objective $20 \times$ Plan-Neofluar $20 \times 10.50$.

Colocalization analysis. The colocalization toolbox JACoP (Just Another Colocalization Plugin) included in the ImageJ software package (Bolte and Cordelières, 2006) was used for quantification of the degree of colocalization between CHL1 and vitronectin, and CHL1 and PAI-2. Three-dimensional photographs were taken on the Olympus confocal laser-scanning microscope under high magnification $(60 \times)$ and processed within the ImageJ software along the $z$-axis. The threshold for each image from the red or green channels was measured, and the pixel gray values of each image from the red channel were plotted against those of each image from the green channel using the JACoP toolbox. For every dual-channel image, a pixel distribution diagram was obtained. From the distribution diagrams, the Pearson's coefficient PC and the Mander's overlap coefficients $\mathrm{M}_{1}$ and $\mathrm{M}_{2}$ were calculated. $P C$ gives the information about the linear correlation between pixel intensity in the green and red images. $M_{1}$ is the ratio of the summed intensities of pixels from a red image, for which the intensity in the green channel is in the range from zero to the maximal intensity, and $\mathrm{M}_{2}$ is defined conversely for a green image (Bolte and Cordelières, 2006). The coefficient values are ranging between +1 and -1 , where +1 is a total positive correlation, 0 is no correlation, and -1 is a total negative correlation. All three parameters were used to compare the degree of colocalization between CHL1 and vitronectin or PAI-2 in 5- and 7-d-old cerebella.

Statistical analysis. All numerical data are presented as group mean values with SEM or SD. Parametric or nonparametric tests were used for comparisons, as indicated in the text and figure legends. Analyses were performed using the SYSTAT 9 software package (SPSS). The threshold value for acceptance of differences was $5 \%$.
(Fig. 1A). The $\sim 165$ and $\sim 200 \mathrm{kDa}$ bands in the CHL1-Fc eluate, and the $\sim 110$ and $\sim 190 \mathrm{kDa}$ bands in the APP-Fc eluate were detected by an antibody against human Fc (Fig. $1 A$ ), indicating that these proteins contain the Fc portion and were thus derived from the bait proteins. Upon silver staining, the protein bands with apparent molecular masses of $\sim 40, \sim 50, \sim 60$, and $\sim 70 \mathrm{kDa}$ were observed in the eluate from CHL1-Fc beads (Fig. $1 A$ ). The bands of $\sim 40$ and $\sim 50 \mathrm{kDa}$ were also observed in the eluate from APP-Fc beads, while no $\sim 60$ and $\sim 70 \mathrm{kDa}$ bands were detectable in this eluate (Fig. $1 A$ ), suggesting that the $\sim 60$ and $\sim 70 \mathrm{kDa}$ proteins are CHL1-binding proteins. The silver stained $\sim 60$ and $\sim 70 \mathrm{kDa}$ protein bands were subjected to mass spectrometry, and two of the detected peptides from the $\sim 70 \mathrm{kDa}$ band could be assigned to vitronectin (Preissner and Reuning, 2011), while the $\sim 60 \mathrm{kDa}$ band could not be assigned to a known protein. The tandem mass spectrometry spectrum of a 1645.8 and 1384.86 Da precursor mass (detected as a doubly charged ion at mass/charge ratios of 823.4 and 692.93) matched the tryptic peptide DVWGIEGPIDAAFTR (1644.79 Da) and INCQGKTYLFK (1385.72 Da) of mouse vitronectin.

To validate the putative interaction between CHL1 and vitronectin, pull-down experiments were performed using CHL1-Fc and detergent-solubilized mouse brain homogenate. Western blot analysis with a vitronectin antibody revealed that CHL1-Fc pulled down vitronectin, whereas vitronectin was not pulled down by L1-Fc (Fig. 1B). Direct binding of vitronectin to the extracellular domain of CHL1 was analyzed by ELISA with substrate-coated vitronectin and increasing concentrations of CHL1-Fc. A concentration-dependent and saturable binding of 

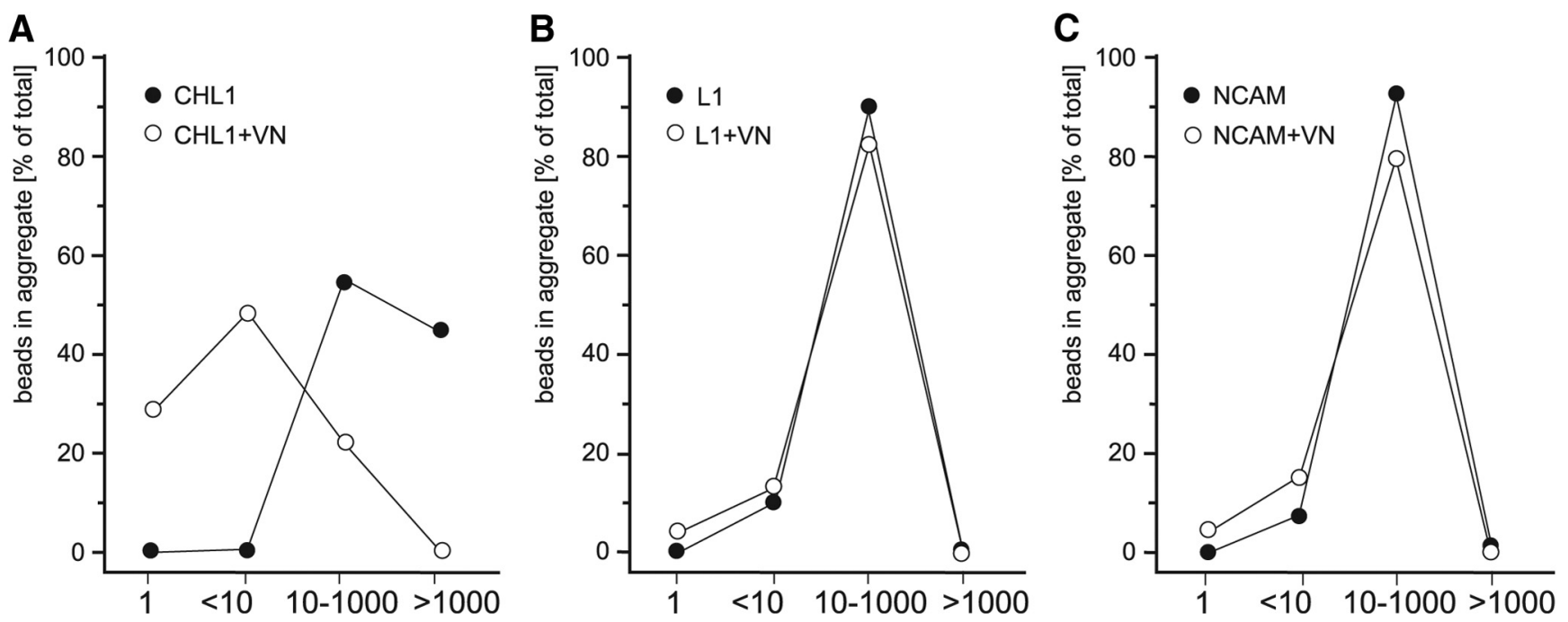

Figure 2. Vitronectin interferes with the homophilic CHL1 interaction. Beads coated with CHL1-Fc, L1-Fc, and NCAM-Fc were incubated in the absence or presence of vitronectin (VN). A-C, Frequency distributions of the number of beads coated with CHL1-FC $(\boldsymbol{A}), \mathrm{L1}-\mathrm{Fc}(\boldsymbol{B})$, and NCAM-Fc $(\boldsymbol{C})$ per aggregate relative to the total number of all beads in the presence or the absence of vitronectin are shown. $p<0.01(\boldsymbol{A}), p>0.05(\boldsymbol{B}, \boldsymbol{C})$ obtained by Kolmogorov-Smirnov test. A representative result of one of three independent experiments is shown.

CHL1-Fc to vitronectin was observed, whereas no binding of L1-Fc or NCAM-Fc to vitronectin was detectable (Fig. 1C).

\section{Vitronectin interferes with the homophilic CHL1 interaction}

Strong homophilic CHL1 binding has been observed in a bead aggregation assay (Jakovcevski et al., 2007). We used this assay to test whether vitronectin interferes with this interaction. Beads were coated with CHL1-Fc, and, for control, with L1-Fc or NCAM-Fc, and were allowed to aggregate in the absence or presence of vitronectin. In the absence of vitronectin, the following strong aggregation of CHL1-Fc-coated beads was observed: $\sim 45 \%$ of the CHL1-Fc-coated beads were in large aggregates of $>1000$ beads per aggregate, and $55 \%$ were found in aggregates of 10-1000 beads per aggregate (Fig. $2 A)$. In the presence of vitronectin, no large aggregates were found, and only $20 \%$ of CHL1-Fc-coated beads were present in aggregates of 10-1000 beads per aggregate (Fig. 2A). Conversely, $\sim 80 \%$ of the CHL1-Fc-coated beads either did not aggregate or were present in small aggregates of up to 10 beads per aggregate (Fig. $2 \mathrm{~A}$ ). In contrast, the aggregation behavior of L1-Fc and NCAM-Fccoated beads was similar in the absence and presence of vitronectin: $\sim 90 \%$ of beads were present in aggregates containing 10-1000 beads per aggregate, and $<10 \%$ were found in small aggregates of $<10$ beads per aggregate (Fig. $2 B, C$ ). These results indicate that vitronectin inhibits the homophilic CHL1 interaction, while it has no effect on the homophilic L1 and NCAM interactions.

A

B
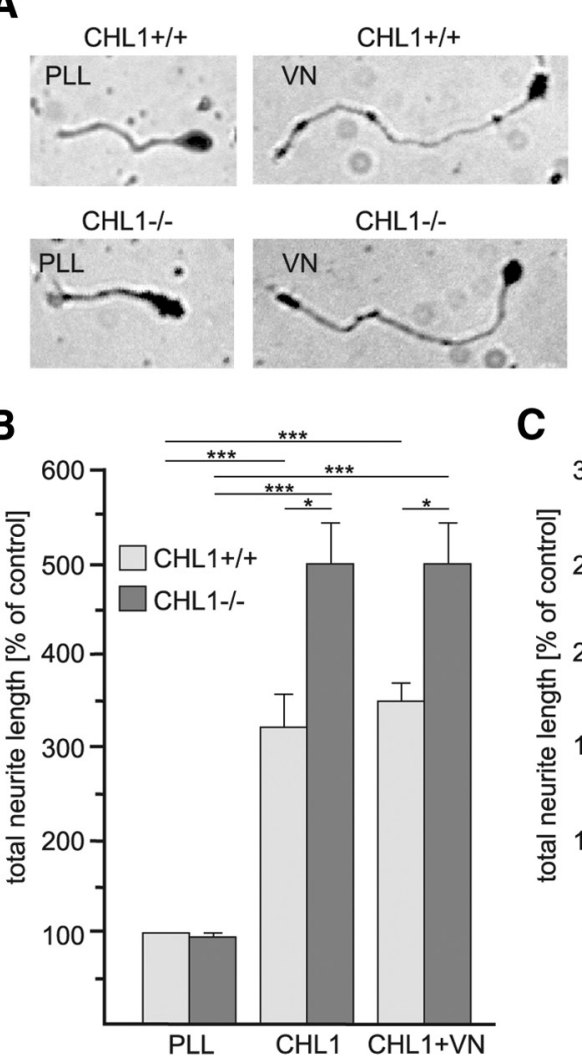

C
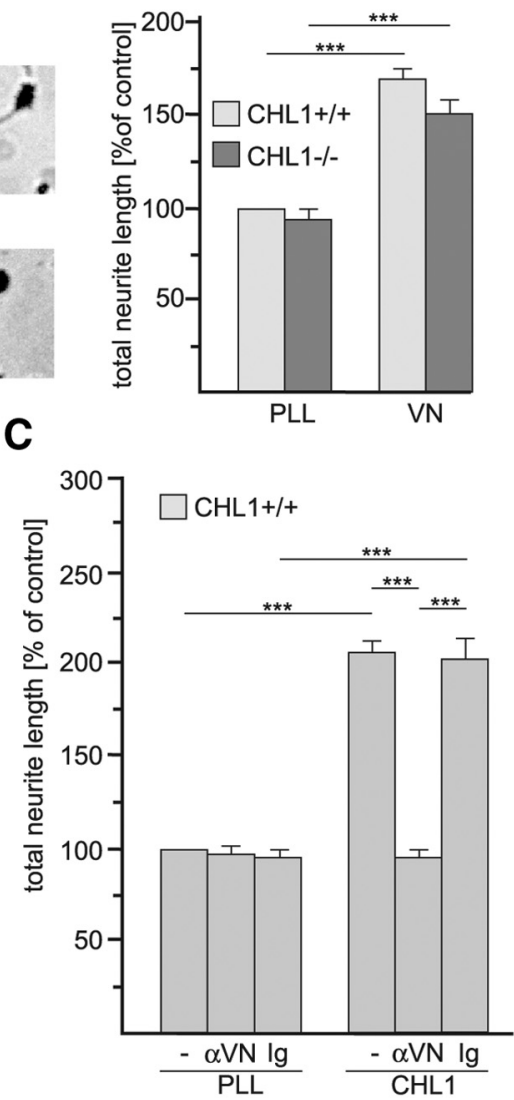

Figure 3. CHL1-induced neurite outgrowth depends on vitronectin. $A-C$, Cerebellar neurons from 6-to 8-d-old wild-type (CHL1 ${ }^{+/+}$;

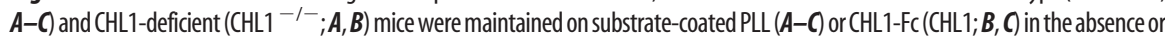
presence of vitronectin $(\mathrm{VN} ; A, B)$, or the absence $(-)$ or presence of vitronectin antibody $(\alpha \mathrm{VN})$ or nonimmune control antibody $(\mathrm{lg} ; \boldsymbol{C})$. Images of representative neurons $(A)$ and mean values \pm SEM of the total lengths of neurites per neuron from three independent experiments counting at least 100 neurons per group in each experiment $(\boldsymbol{A}-\boldsymbol{C})$ are shown. The groups were analyzed by one-way ANOVA with Tukey's multiple-comparison test, and significant differences between groups $\left({ }^{*} p<0.05 ;{ }^{* * *} p<0.001\right)$ are indicated.

Trans-interactions of CHL1 with integrins and vitronectin trigger neurite outgrowth

In in vitro experiments, homophilic CHL1 trans-interactions inhibit neurite outgrowth, whereas heterophilic CHL1 trans- 
interactions promote neurite outgrowth (Jakovcevski et al., 2007). To investigate whether vitronectin affects CHL1-dependent neurite outgrowth, we incubated wild-type and CHL1-deficient cerebellar neurons on substrate-coated PLL or CHL1-Fc in the absence or presence of vitronectin and determined the total lengths of neurites per cell. Vitronectin promoted neurite outgrowth of wild-type and CHL1-deficient cerebellar neurons from 6- to 8-dold mice grown on PLL (Fig. $3 A$ ), but did not alter the pronounced enhancement of neurite outgrowth from wild-type and CHL1-deficient cerebellar neurons by CHL1-Fc (Fig. 3B). These results indicate that the promotion of neurite outgrowth by vitronectin does not depend on CHL1 at the neuronal surface and that neurite outgrowth triggered by heterophilic CHL1 transinteractions is not affected by the addition of exogenous vitronectin to the cultures.

Next, we tested whether CHL1-enhanced neurite outgrowth is affected when the function of endogenous vitronectin is blocked by a vitronectin antibody. CHL1-induced neurite outgrowth was reduced to control values in the presence of the vitronectin antibody, but was not altered by a nonimmune control antibody (Fig. $3 \mathrm{C}$ ), indicating that CHL1-triggered neurite outgrowth depends on endogenous vitronectin.

CHL1 contains the integrin-binding motifs Arg-Gly-Asp (RGD) in the second Ig-like domain and Asp-Gly-Glu-Ala (DGEA) in the sixth Ig-like domain, interacts with $\beta 1$ integrins in cis-position, and functions as a coreceptor of integrins to enhance cell migration and neuritogenesis (Buhusi et al., 2003). Thus, we determined neurite outgrowth on CHL1-Fc in the absence or presence of CHL1-specific peptides containing the RGD or DGEA motif. Peptides with mutations of RGD to KGE or DGEA to AGEV served as controls. In the presence of the RGDcontaining peptide, promotion of neurite outgrowth of wild-type and CHL1-deficient cerebellar neurons from 6- to 8-d-old mice was abolished on the CHL1-Fc substrate and reached values observed for neurite outgrowth on PLL (Fig. 4A). The peptides with the mutated RGD motif as well as the nonmutated and mutated DGEA motifs did not affect CHL1-enhanced neurite outgrowth (Fig. 4A). When L1-Fc was used as substrate coat, none of the peptides altered L1-promoted neurite outgrowth (Fig. 4B), indicating that the CHL1-derived peptide with the RGD motif inhibits the interaction of CHL1 with distinct integrins and that these integrins do not interact with L1. The results show that interaction of CHL1 with specific integrins via its RGD motif triggers neurite outgrowth, whereas the DGEA motif does not play a role in CHL1-induced promotion of neurite outgrowth.

\section{CHL1 interacts with PAI-2}

To identify further binding partners for CHL1, we additionally screened a peptide phage display library with CHL1-Fc as bait and identified a binding peptide with sequence similarity to a sequence stretch within PAI-2 (Fig. 5A), suggesting that CHL1 interacts with PAI-2. Coimmunoprecipitation experiments were performed to probe for this association using brain homogenates from wild-type, CHL1-deficient, and L1-deficient mice. When a CHL1 antibody against the extracellular domain was used for immunoprecipitation, Western blot analysis with a PAI-2 antibody detected PAI-2 in CHL1 immunoprecipitates from the homogenate of wild-type, but not from CHL1-deficient brains (Fig. $5 B$ ). Negligible amounts of PAI-2 were observed in the immunoprecipitates from wild-type and L1-deficient mouse brains when an antibody against the extracellular domain of L1 was used for immunoprecipitation (Fig. 5B). This finding supports the notion that CHL1 and PAI-2 are associated with each other. To deter-

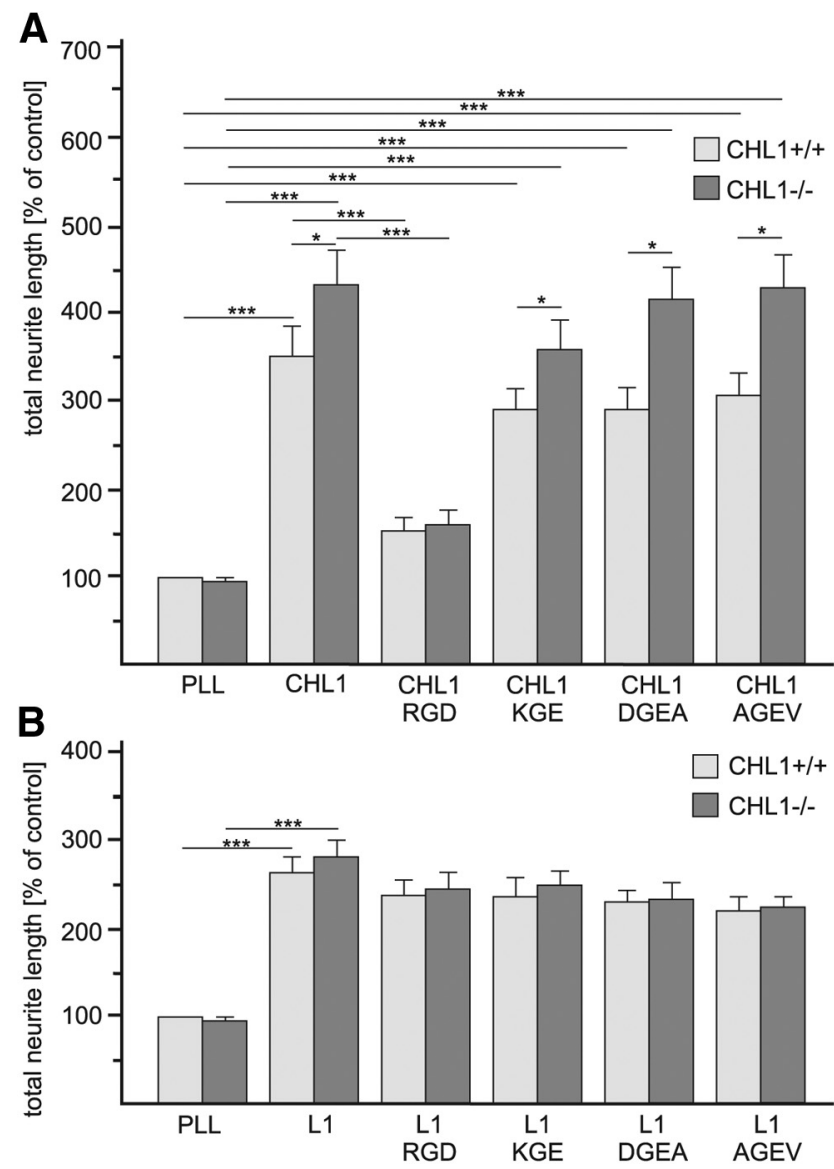

Figure 4. CHL1 mediates neurite outgrowth via its RGD integrin-binding motif. $A, B$, Cerebellar neurons from 6 - to 8 -d-old $\mathrm{CHL} 1$-deficient $\left(\mathrm{CHL}^{-/-}\right)$or wild-type $\left(\mathrm{CHL} 1^{+/+}\right)$mice were maintained on substrate-coated PLL, CHL1-Fc (CHL1; $\boldsymbol{A})$, or L1- $\mathrm{Fc}(\mathrm{L} 1 ; \boldsymbol{B})$ in the absence or presence of $C H L 1$ peptides with the RGD or DGEA motif or with mutation of the motifs to KGE and AGEV. The total lengths of neurites per neuron were determined, and mean values \pm SEM from three independent experiments counting at least 100 neurons per group in each experiment are shown. The groups were analyzed by one-way ANOVA with Tukey's multiple-comparison test, and significant differences between groups $\left({ }^{*} p<0.05 ;{ }^{* * *} p<0.001\right.$ ) are indicated.

mine a direct interaction between PAI-2 and CHL1, a label-free binding assay was performed. Soluble recombinant PAI-2 showed a concentration-dependent binding to substrate-coated CHL1-Fc and negligible binding to Fc (Fig. 5C). Similarly, soluble CHL1-Fc, but not Fc, bound to immobilized PAI-2 in a concentration-dependent manner, indicating a direct interaction between PAI-2 and CHL1. Interestingly, L1-Fc as well as NCAM-Fc bound also to immobilized PAI-2 (Fig. $5 C$ ), suggesting that PAI-2 binds not only to CHL1 in vitro, but also to other recombinantly expressed cell adhesion molecules of the Ig superfamily.

\section{CHL1 colocalizes with vitronectin and PAI-2 in the developing cerebellar cortex}

The in vitro findings of direct interactions of CHL1-Fc with vitronectin and PAI-2 suggest that CHL1 also interacts with vitronectin and PAI-2 in vivo. To test this possibility, immunostainings of CHL1, vitronectin, and PAI-2 in cerebellum from 5- and 7-d-old mice were performed. Colocalization of CHL1 with vitronectin and PAI-2 was observed in the cerebellum of 7-d-old mice (Figs. $6 A-C, 7 A-C$ ), but not in the cerebellum of 5-d-old mice (Figs. $6 D-F, 7 D-F$ ). Colocalization was observed along radial fibers of Bergmann glial cells, and at cells located 
within the inner region of the external granular layer, within the molecular layer, and within in the internal granular layer near the Purkinje cell layer (Figs. $6 A-C$, $7 A-C)$. Quantification of the coimmunostaining of CHL1 with vitronectin or PAI-2 showed that a pronounced fraction of the CHL1 signals overlapped with the vitronectin and PAI-2 signals in cerebella of 7-d old mice, while only a small fraction of the CHL1 signals overlapped with the vitronectin and PAI-2 signals in cerebella of 5-d-old mice (Figs. 6G, 7G).

Using an alternative method to confirm that CHL1 interacts with vitronectin and PAI-2, we performed proximity ligation assays. This method allows the generation and amplification of fluorescent signals from a pair of oligonucleotide-labeled secondary antibodies when two primary antibodies are bound to their antigens in close proximity. This technology has proven to be suitable for detection of direct protein interactions with high sensitivity and specificity. Fluorescent spots were found in cerebella of 7-d-old mice at cells located within the inner region of the external granular layer, within the molecular layer, and within the internal granular layer (Figs. $6 \mathrm{H}, 7 \mathrm{H}$ ), indicating that CHL1 interacts significantly with vitronectin and PAI-2 at this developmental stage. In contrast, no or only a few small fluorescent spots were found in cerebella of 5-d-old mice (Figs. 6I, 7I), indicating that CHL1 does not interact with vitronectin or PAI-2 at this younger stage.

In summary, these findings suggest that CHL1 interacts with vitronectin and PAI-2 on migrating granule cells at a time point when granule cell migration from the external to the internal granular layer is prominent (at approximately postnatal day 7), and that vitronectin and PAI-2 are involved in CHL1-dependent granule cell migration along Bergmann glial processes.

\section{Trans-interactions of CHL1 with vitronectin and $\alpha v \beta 1$ or $\alpha v \beta 3$ integrin trigger neurite outgrowth}

Vitronectin binds to $\alpha \mathrm{v} \beta 3$ and $\alpha \mathrm{v} \beta 1$ integrins (Bodary and McLean, 1990; Horton, 1997), whereas CHL1 interacts with $\beta 1$ and possibly $\alpha 1$ and $\alpha 2$ integrins (Buhusi et al., 2003). Since CHL1-Fc-triggered neurite outgrowth is mediated by the RGD motif in CHL1, we investigated whether CHL1 interacts with the RGD receptors $\alpha \mathrm{v} \beta 3$ and/or $\alpha \mathrm{v} \beta 1$ integrin to regulate CHL1induced neurite outgrowth using antibodies against the $\alpha \mathrm{v}, \beta 1$, and/or $\beta 3$ integrin subunits. In parallel, two independent PAI-2 antibodies were used to investigate the role of PAI-2 in CHL1induced neurite outgrowth. Antibodies against the $\alpha \mathrm{v}, \beta 1$, or $\beta 3$ integrin subunits and against vitronectin reduced the enhanced neurite outgrowth on substrate-coated CHL1-Fc to values observed on the control substrate PLL, while neither of the two PAI-2 antibodies affected neurite outgrowth on CHL1-Fc (Fig. 8). All tested antibodies did not alter the basal neurite outgrowth on PLL (Fig. 8). The results indicate that the promotion of neurite outgrowth by CHL1 involves the RGD-dependent vitronectin receptors $\alpha \mathrm{v} \beta 1$ and $\alpha \mathrm{v} \beta 3$ integrin, but not PAI-2.

To further analyze whether CHL1-Fc is associated with vitronectin or $\alpha \mathrm{v} \beta 1$ and $\alpha \mathrm{v} \beta 3$ integrins, we treated live CHL1-deficient cerebellar neurons with CHL1-Fc and, after fixation, stained the cells with antibodies against human $\mathrm{Fc}$, vitronectin, and $\alpha \mathrm{v}, \beta 1$, or $\beta 3$ integrin subunits. Pronounced colabeling of CHL1-Fc, vitronec-
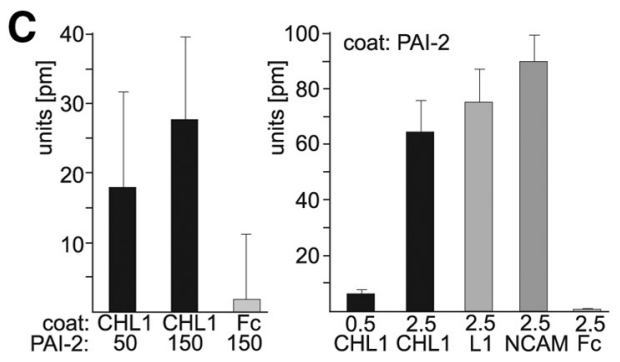

WB: PAI-2

Figure 5. CHL1 interacts with PAI-2. A, The peptide sequence, which is derived from a phage that bound to $\mathrm{CHL} 1-\mathrm{FC}$ and a peptide stretch of PAl-2 with sequence similarity to the phage peptide, is depicted. Identical amino acids are indicated by bars. $\boldsymbol{B}$,

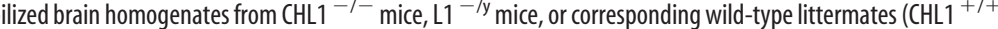
representative Western binant PAI-2 and substrate-coated CHL1-Fc and Fc, or 0, 0.5, and 2.5 nм CHL1-Fc and Fc with substrate-coated PAI-2. Mean values \pm SD of reflected wavelength shifts from three independent experiments performed in triplicate are shown.

tin, and $\alpha \mathrm{v}$ integrins predominantly along neurites (Fig. $9 A$ ), and a strong costaining of CHL1-Fc, vitronectin, and $\beta 1$ integrins along neurites and at cell bodies were observed (Fig. $9 B$ ), indicating colocalization of CHL1-Fc and vitronectin with $\alpha \mathrm{v}$ and $\beta 1$ integrins. In contrast, staining with an antibody against the $\beta 3$ integrin subunit revealed only a partial colocalization of CHL1-Fc and $\beta 3$ integrins, but showed strong colocalization of $\beta 3$ integrins with vitronectin (Fig. $9 C$ ). Since vitronectin has been proposed to bind to $\alpha 3 \beta 1$ integrin (Wei et al., 2001; Smith and Marshall, 2010), we tested whether CHL1 and vitronectin colocalize with $\alpha 3$ integrins and indeed observed a significant colocalization of CHL1-Fc, vitronectin, and $\alpha 3$ integrins predominantly along neurites (Fig. 9D). Similarly, a strong colocalization of CHL1-Fc with $\alpha 2$ and $\alpha 1$ integrins was observed predominantly at cell bodies and along neurites, respectively (Fig. $9 E, F)$. In contrast, CHL1-Fc did not colocalize with $\alpha 6$ integrin and showed only a weak colocalization with $\alpha 7$ integrin (Fig. 9G,H). Interestingly, CHL1-Fc showed prominent colocalization with PAI-2, but not with PAI-1, while PAI-1 as well as PAI-2 colocalized with vitronectin (Fig. 9I,J). These results indicate that CHL1 is associated with vitronectin; PAI-2; and $\alpha \mathrm{v} \beta 1, \alpha 3 \beta 1$, $\alpha 2 \beta 1, \alpha 1 \beta 1$, and $\alpha v \beta 3$ integrins. Since PAI-2, which is one of the two inhibitors that regulate the serine protease activity of uPA, interacts with CHL1-Fc, we analyzed whether uPA and its UPAR colocalize with CHL1. Colocalization of uPA with CHL1-Fc could be detected mainly on cell bodies, but no significant colocalization of CHL1-Fc with uPAR could be observed (Fig. $9 \mathrm{~K}, L$ ). No staining of tubulin was observed under the fixation conditions used (Fig. 9M), while strong intracellular tubulin staining was seen after detergent permeabilization of the fixed cells (Fig. $9 N)$, demonstrating the impermeability of cells after fixation. In summary, the results indicate that CHL1 is associated with vitronectin; PAI-2; and $\alpha \mathrm{v} \beta 1, \alpha 3 \beta 1, \alpha 2 \beta 1, \alpha 1 \beta 1$, and $\alpha \mathrm{v} \beta 3$ integrins at the cell surface of cerebellar neurons.

\section{Trans-interactions of CHL1 with integrins, vitronectin, and PAI-2 trigger neuronal migration in a uPA/uPAR-dependent manner}

In cultures of explants from cerebella of 7-d-old mice, migration of CHL1-deficient cells is severely impaired (Jakovcevski et al., 2007). Since granule cells represent $\sim 90 \%$ of all cells in the cerebellum, this result indicates that granule cell migration is impaired in the absence of CHL1 in vitro. Impaired migration of granule cells was also observed in vivo in cerebella of CHL1deficient mice at postnatal day 7 (Jakovcevski et al., 2009). We 

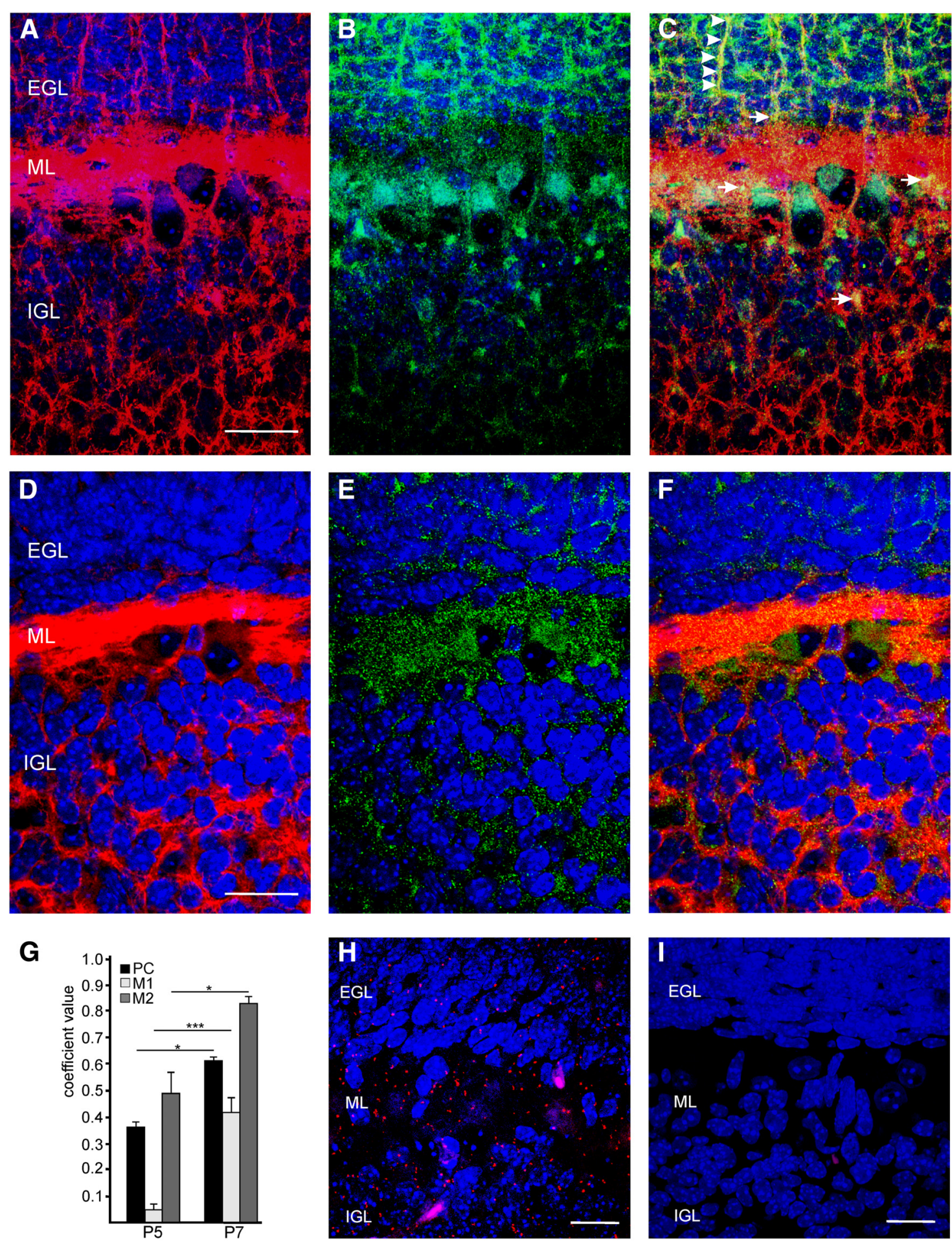

Figure 6. CHL1 and vitronectin colocalize in the cerebellum of 7-d-old mice, but not 5-d-old mice. $A, B, D, E$, Representative image of immunofluorescence staining for DAPI (blue) and CHL1 (red; $\boldsymbol{A}, \boldsymbol{D})$, and DAPI and vitronectin (VN; green; $\boldsymbol{B}, \boldsymbol{E}$ ) are shown. $\boldsymbol{C}, \boldsymbol{F}$, Superimposition indicates colocalizations as yellow along radial fibers of Bergmann glial cells (arrowheads), and at cells located within the molecular layer and the external and internal granular layers (arrows). Scale bars, $15 \mu \mathrm{m}$. G, Pearson's coefficient $P\left(\right.$ and the Mander's overlap coefficients $\mathrm{M}_{1}$ and $\mathrm{M}_{2}$ were calculated as parameters for the degree of colocalization between $\mathrm{CHL} 1$ and vitronectin. Coefficient values \pm SEM for cerebella from postnatal day 5 (P5) and P7 as well as wild-type mice $(n=6)$ are shown. The groups were analyzed by two-tailed Student's $t$ test, and significant differences between groups $\left({ }^{*} p<0.01 ;{ }^{* * *} p<0.001\right)$ are indicated. $\boldsymbol{H}, \boldsymbol{I}$, Representative images from the proximity ligation assay are shown. Red spots indicate close interaction of CHL1 with vitronectin. Scale bars, $60 \mu \mathrm{m} . \boldsymbol{A}-\boldsymbol{C}, \boldsymbol{H}, 7-\mathrm{d}$-old cerebella. D-F, I, 5-d-old cerebella. EGL, External granular layer; ML, molecular layer; PCL, Purkinje cell layer; IGL, internal granular layer.

thus investigated whether application of CHL1-Fc to explant cultures affects migration of wild-type or CHL1-deficient cerebellar granule cells. When maintained on CHL1-Fc substrate, the number of wild-type and CHL1-deficient cells migrating out of the explants derived from cerebella of 7-day-old mice was increased compared with the number observed on the PLL substrate (Fig. $10 A-C$ ), indicating that CHL1 triggers the migration of granule cells. On both substrates, the total number of migrat- 

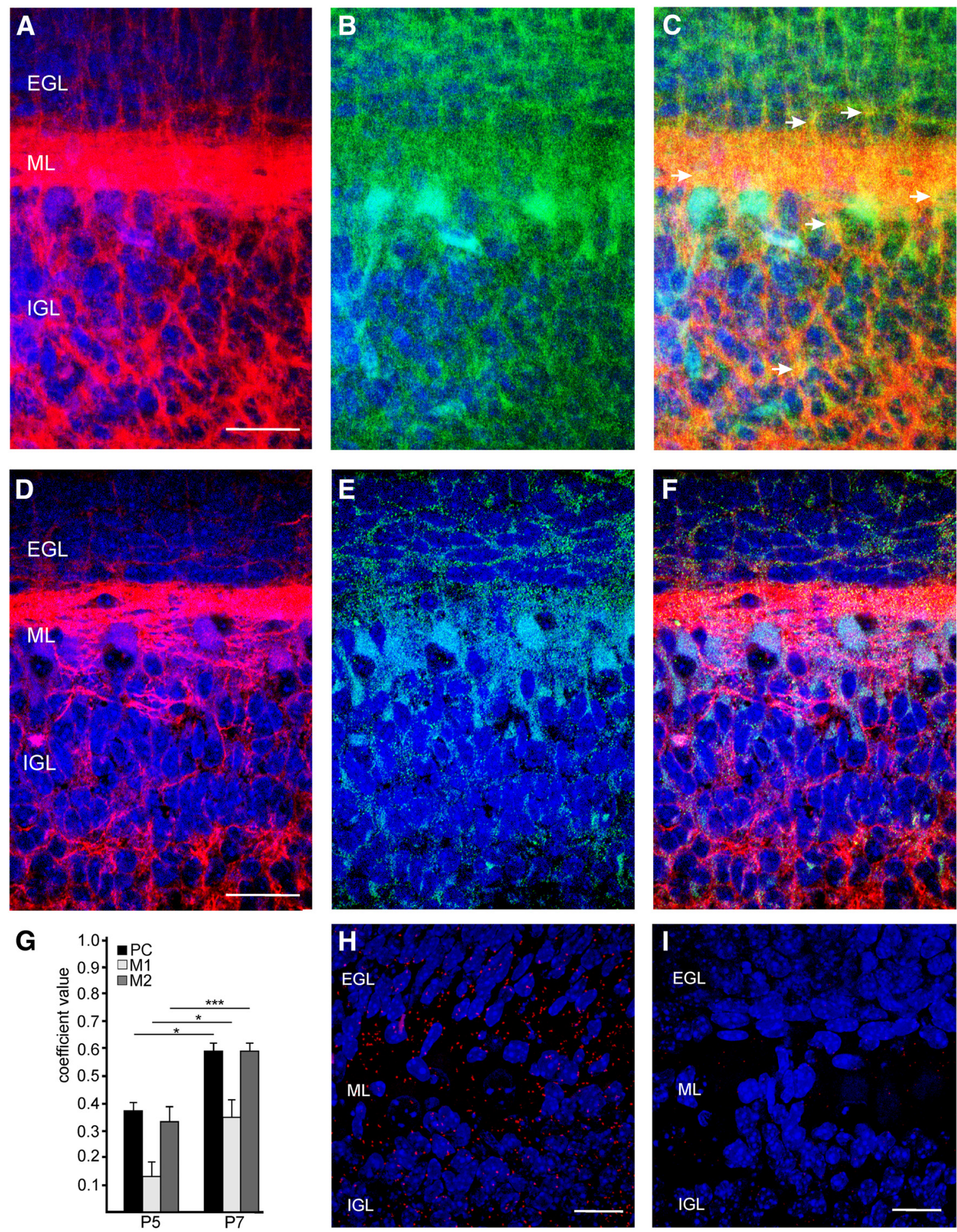

Figure 7. CHL1 colocalizes with PAI-2 in 7-d-old cerebellum, but not in 5-d-old cerebellum. $A, B, D, E$, Representative image of immunofluorescence staining for DAPI (blue) and CHL1 (red; $A, D$ ) and DAPI and PAl-2 (green; $\boldsymbol{B}, \boldsymbol{E}$ ) are shown. $\boldsymbol{C}, \boldsymbol{F}$, Superimposition indicates colocalizations as yellow at cells located within the molecular layer and the external and internal granular layers (arrows). Scale bars, $15 \mu \mathrm{m}$. G, Pearson's coefficient PC and the Mander's overlap coefficients $M_{1}$ and $M_{2}$ were calculated as parameters for the degree of colocalization between CHL1 and vitronectin. Coefficient values \pm SEM for cerebella from postnatal day 5 (P5) and P7 as well as wild-type mice $(n=6)$ are shown. The groups were analyzed by two-tailed Student's $t$ test, and significant differences between groups $\left({ }^{*} p<0.01 ;{ }^{* * *} p<0.001\right)$ are indicated. $\boldsymbol{H}, \boldsymbol{I}$, Representative images from proximity ligation assay are shown. Red spots indicate the close interaction of $C H L 1$ with PAI2. Scale bars, $60 \mu \mathrm{m} . \boldsymbol{A}-\boldsymbol{C}, \boldsymbol{H}, 7$-d old cerebella. D-F, I, 5-d-old cerebella. EGL, External granular layer; ML, molecular layer; PCL, Purkinje cell layer; IGL, internal granular layer.

ing CHL1-deficient cells was lower than those of wild-type cells (Fig. 10C).

To analyze the CHL1-induced migration in more detail, the number of cells in defined distance intervals was measured. On PLL, a similar number of CHL1-deficient and wild-type cells migrated up to $50 \mu \mathrm{m}$ away from the explant border (Fig. 10D).
When compared with the numbers of migrating wild-type cells, fewer CHL1-deficient cells migrated up to 100, 150, or $200 \mu \mathrm{m}$ (Fig. 10D). On the CHL1-Fc substrate, more wild-type than CHL1-deficient cells migrated up to $300 \mu \mathrm{m}$, whereas similar numbers of wild-type and CHL1-deficient cells migrated up to 400 and $\geq 500 \mu \mathrm{m}$ (Fig. 10E). 


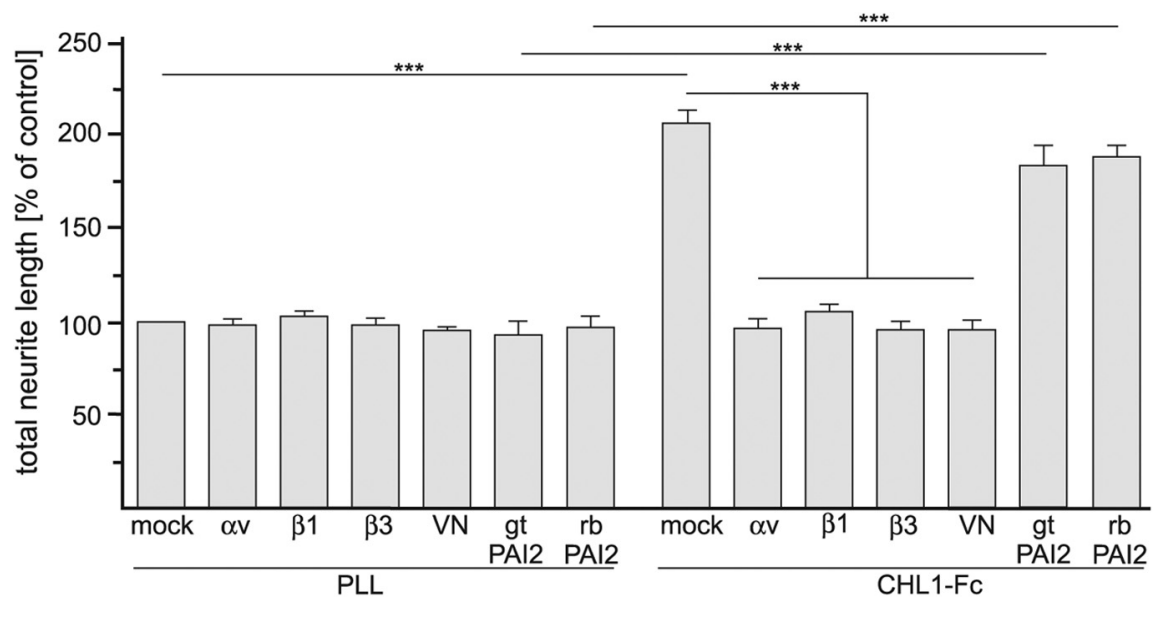

Figure 8. CHL1-induced neurite outgrowth depends on vitronectin, and $\alpha_{\mathrm{v}^{\prime}}, \beta_{3}$, and/or $\beta_{1}$ integrins, but not on PAl-2. Cerebellar neurons from 6- to 8-d-old CHL1-deficient mice were maintained on substrate-coated PLL or CHL1-Fc in the absence or presence of rabbit antibodies against vitronectin (VN), PAl-2 (rb PAl-2), or goat antibodies against integrin subunits $\alpha \mathrm{V}, \beta 1, \beta 3$, or PAl-2 (gt PAI-2). The total lengths of neurites per neuron were determined, and mean values \pm SEM from three independent experiments counting at least 100 neurons per group in each experiment are shown. The groups were analyzed by one-way ANOVA with Tukey's multiple-comparison test, and significant differences between groups $\left({ }^{* * *} p<0.001\right)$ are indicated.

cell migration, while a scrambled version of this peptide had no effect (Fig. 11A). The CHL1-derived peptide with the RGD motif also blocked CHL1-induced migration, while neither the peptide with the integrin-binding DGEA motif nor the peptides with the mutated motifs altered CHL1-enhanced migration (Fig. 11A). Antibodies against $\alpha \mathrm{v}, \alpha 1, \alpha 2, \alpha 3, \beta 1$, and $\beta 3$ integrin subunits reduced granule cell migration, while antibodies against $\alpha 4$, $\alpha 5, \alpha 6, \alpha 7$, and $\beta 2$ integrin subunits had no effect (Fig. 11B). Neither antibodies nor peptides had an effect on neuronal migration on PLL (data not shown). These results indicate that CHL1triggered migration of granule cells depends on the interaction and functional interplay of CHL1 with vitronectin; PAI-2; uPA; uPAR; and $\alpha \mathrm{v} \beta 1, \alpha 1 \beta 1$, $\alpha 2 \beta 1, \alpha 3 \beta 1$, and/or $\alpha \mathrm{v} \beta 3$ integrins.

Since CHL1-triggered migration is inhibited by vitronectin and PAI-2 antibod-

To distinguish whether the reduced number of migrating CHL1-deficient cells is due to retarded migration and/or to a missing or nonmigrating subpopulation of CHL1-deficient cells, we calculated the percentages of migrating neurons for the individual distance intervals relative to the total number of migrating cells. When maintained on PLL, the relative number of CHL1deficient cells in the distance interval near the explant border $(<50 \mu \mathrm{m})$ was higher than that of wild-type cells, while the relative numbers in the other intervals were lower (Fig. 10F), indicating retarded migration of CHL1-deficient cells in the absence of CHL1, leading to an accumulation of cells near the explant border. On the CHL1-Fc substrate, the relative numbers of CHL1-deficient and wild-type cells were similar in all distance intervals (Fig. 10G), showing that migration of CHL1-deficient cells is similar to that of wild-type cells when CHL1-Fc is present as a homophilic trans-interacting molecule. The higher number of migrating wild-type granule cells relative to CHL1-deficient granule cells migrating up to $300 \mu \mathrm{m}$ suggests that a significant portion of CHL1-deficient granule cells does not migrate and/or that a subpopulation of granule cells is missing.

Since CHL1 triggers granule cell migration and interacts with vitronectin and integrins, we analyzed whether the interaction of CHL1 with vitronectin and integrins regulates the migration of granule cells. In addition, we tested whether PAI-1 and/or PAI- 2 and their interaction partners UPA and UPAR are involved in CHL1induced migration. To exclude homophilic CHL1 interactions and to study only the heterophilic CHL1 interactions, cerebellar explants from CHL1-deficient mice were used and maintained on substratecoated PLL; CHL1-Fc in the absence and presence of antibodies against the different integrin subunits, vitronectin, PAI-2, PAI-1, $\mathrm{uPA}$, and $\mathrm{uPAR}$; in the presence of the putative CHL1-binding PAI2-derived peptides; or the CHL1-derived peptides with integrinbinding motifs. Compared with the number of cells migrating out from explants on PLL, three to four times more cells migrated out of the explants on the CHL1-Fc substrate (Fig. 11A). This CHL1enhanced cell migration was reduced to PLL values by antibodies against vitronectin, PAI-2, uPA, and uPAR, but not by an antibody against PAI-1 (Fig. 11A).

Likewise, the putative CHL1-binding peptide comprising amino acids 335-349 of PAI-2 inhibited CHL1-induced granule ies reacting with $\mathrm{N}$-terminal epitopes, and by the PAI-2-derived peptide with a C-terminal sequence stretch, we tested whether a recombinant $\mathrm{N}$-terminal vitronectin fragment or recombinant $\mathrm{N}$ - and C-terminal PAI-2 fragments affect CHL1-dependent migration. Beforehand, we verified by label-free binding assay and ELISA that CHL1-Fc binds to these recombinant fragments. CHL1-Fc showed a pronounced binding to all fragments in both assays (Fig. 12 A, B). No binding of Fc was detectable in the labelfree binding assay (data not shown), while low binding of Fc to the C-terminal PAI-2 fragment and negligible binding to the $\mathrm{N}$-terminal PAI-2 and vitronectin fragments was seen in ELISA (Fig. 12B). Interestingly, vitronectin also did not show any binding to the PAI-2 fragments in the label-free binding assay (Fig. $12 \mathrm{~A}$ ), indicating that vitronectin does not directly bind to PAI-2. In both assays, L1-Fc showed binding to the C-terminal PAI-2 fragment, but low binding to the N-terminal PAI-2 and vitronectin fragments (Fig. 12A,B). These results suggest that the $\mathrm{N}$-terminal parts of vitronectin and PAI-2 mediate the specific interaction with CHL1, while the C-terminal part of PAI-2 mediates the interaction of PAI-2 with CHL1 and L1.

In the absence of CHL1-Fc, the N-terminal vitronectin fragment enhanced the migration of neurons from wild-type, but not CHL1-deficient, explants (Fig. 12C). The N-terminal PAI-2 fragment did not stimulate migration, while the C-terminal PAI-2 fragment triggered migration from wild-type and CHL1deficient explants in the absence of CHL1-Fc (Fig. 12C). All fragments interfered with the CHL1-Fc-enhanced cell migration from CHL1-deficient explants, while only the N-terminal vitronectin fragment blocked the CHL1-induced migration in wildtype explants (Fig. 12C). These results indicate that these fragments are capable of disturbing heterophilic CHL1 transinteractions; that the $\mathrm{N}$-terminal vitronectin fragment interferes with the homophilic CHL1 cis-interaction in wild-type cells, thus enhancing migration; and that the C-terminal PAI-2 fragment stimulates migration in a CHL1-independent manner.

\section{Homophilic CHL1 trans-interactions reduce neuronal differentiation}

Our experiments on neuronal migration suggest that a subpopulation of CHL1-deficient granule cells does not migrate, is post- 
A

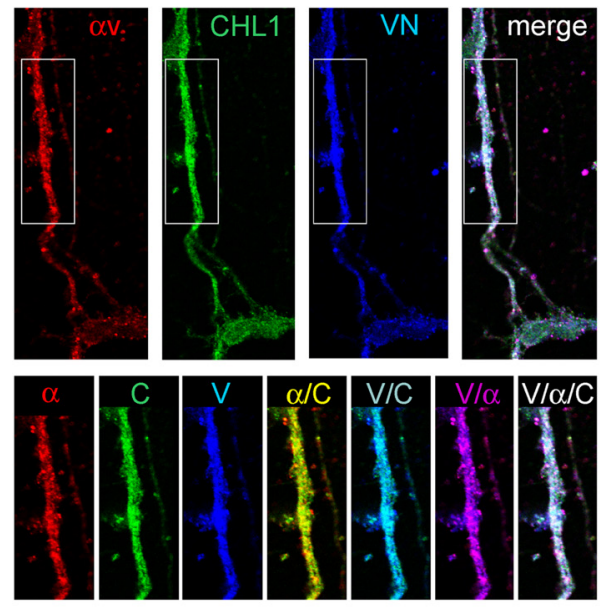

C
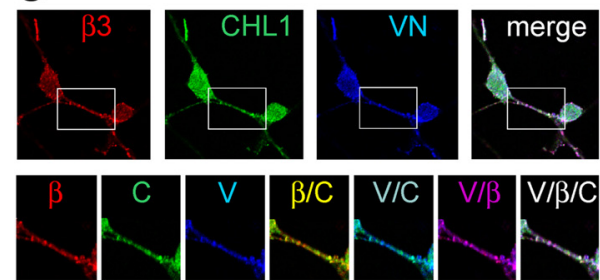

E

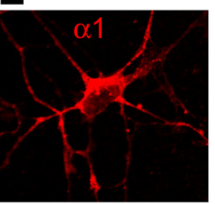

G

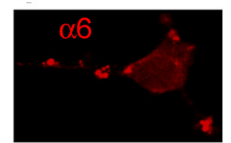

I
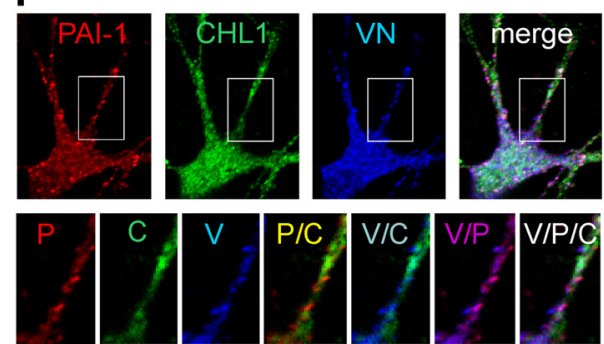

K

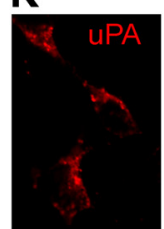

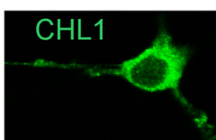
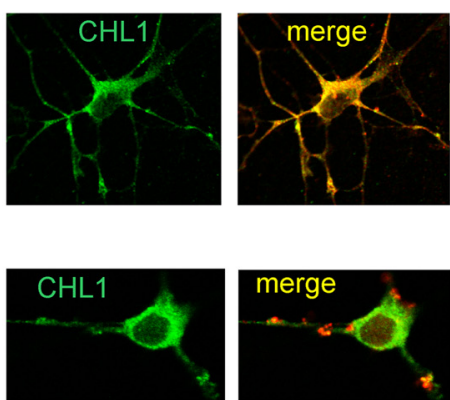

L
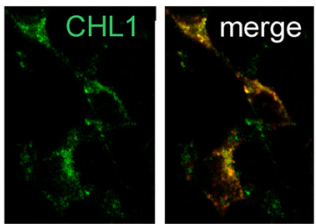

B
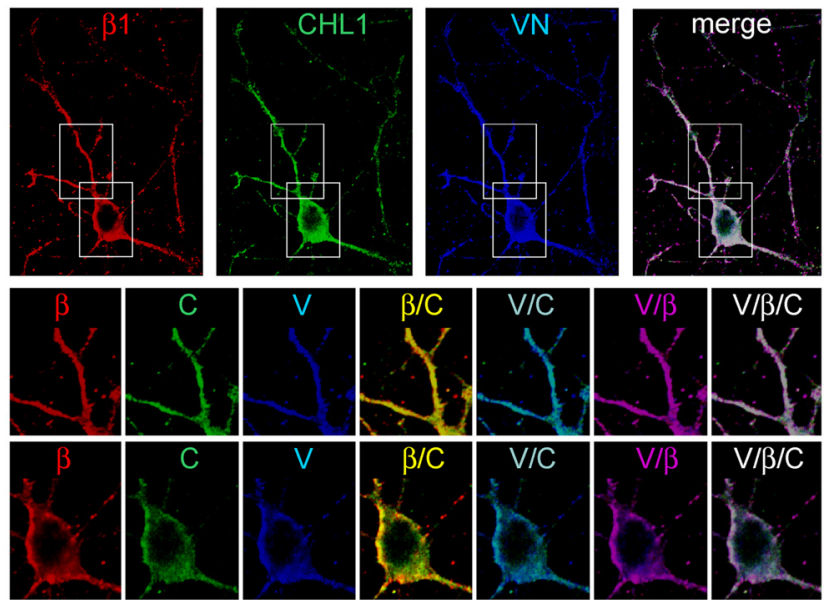

D
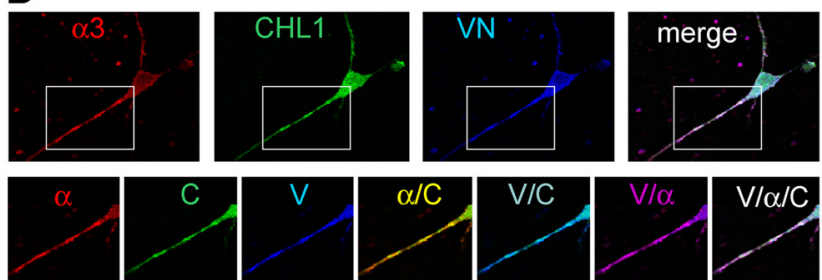

F
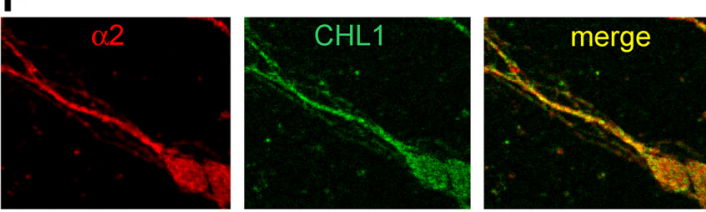

H
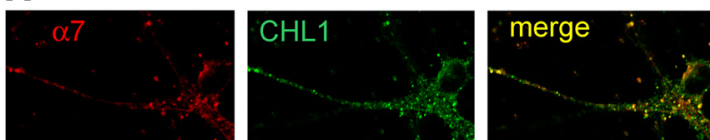

J
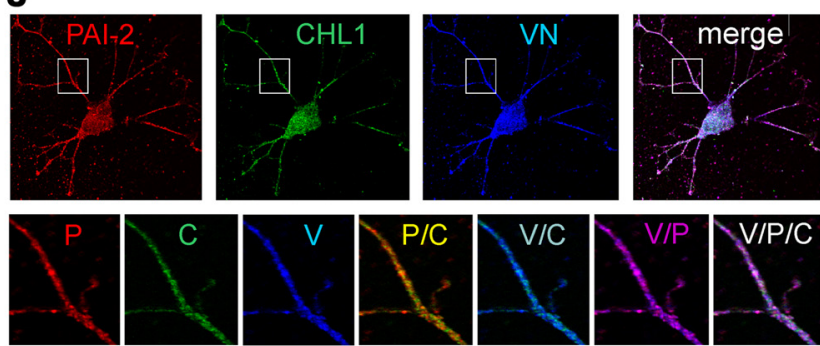

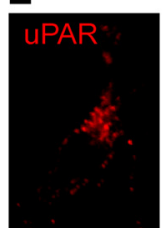

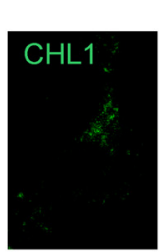
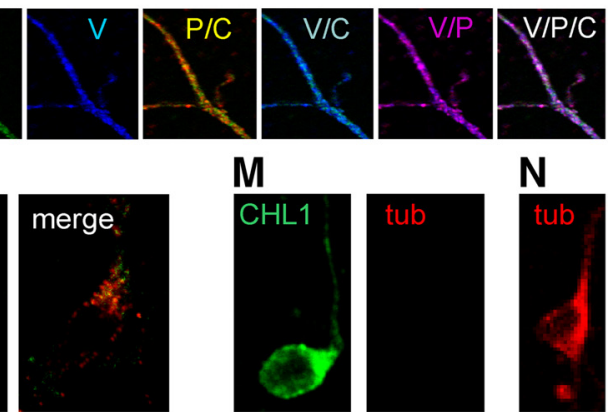

Figure 9. CHL1 colocalizes with vitronectin, integrins, and PAI-2. Live CHL1-deficient cerebellar neurons from 6- to 8-d-old CHL1-deficient mice were incubated with CHL1-Fc. $\boldsymbol{A}-\boldsymbol{M}$, After fixation, cells were first incubated with goat antibodies against $\alpha \mathrm{v}(\boldsymbol{A}), \beta 1(\boldsymbol{B}), \beta 3(\boldsymbol{C}), \alpha 3(\boldsymbol{D}), \alpha 6(\boldsymbol{G})$, or $\alpha 7(\boldsymbol{H})$ integrin subunit, PAl-1 (I) or PAl-2 $(\boldsymbol{J})$; with mouse antibodies against $\alpha_{1}(\boldsymbol{E})$ or $\alpha_{2}(\boldsymbol{F})$ integrin subunit and with rabbit antibodies against vitronectin (VN; $\boldsymbol{A}-\boldsymbol{D}, \boldsymbol{I}, \boldsymbol{J})$, uPA $(\boldsymbol{K})$, uPAR ( $\boldsymbol{L}$ ), or tubulin $(\boldsymbol{M})$, and then with Cy2-conjugated anti-human Fc (green), Cy3-conjugated anti-goat (red; $\boldsymbol{A}-\boldsymbol{M}$ ) and (y5-conjugated anti-rabbit (blue; $\boldsymbol{A}-\boldsymbol{D}, \boldsymbol{I}, \boldsymbol{J}$ ) antibodies. $\boldsymbol{N}$, Cells were fixed, permeabilized, and incubated with tubulin antibody and (y3-conjugated secondary antibody (red). Colocalization of CHL1 and $\alpha$ v or $\alpha 3$ integrin subunit $(\alpha / \mathrm{C}), \beta 1$ or $\beta 3(\beta / \mathrm{C})$ integrin subunit, or PAl-2 (P/C) is shown in yellow. Colocalization of vitronectin and $\mathrm{CHL} 1 \mathrm{~V} / \mathrm{C})$ or PAI-2 (V/P) is shown in pink. Colocalization of vitronectin and $\alpha \mathrm{v}$ or $\alpha 3$ integrin subunit $(\mathrm{V} / \alpha)$ and $\beta 1$ or $\beta 3(\mathrm{~V} / \beta)$ integrin subunit is shown in turquoise. Colocalization of CHL1; vitronectin; and $\alpha \mathrm{V}$ or $\alpha 3$ integrin subunit $(\mathrm{V} / \alpha / \mathrm{C}), \beta 1$ or $\beta 3(\mathrm{~V} / \beta / \mathrm{C})$ integrin subunit, or PAI-2 $(\mathrm{V} / \mathrm{P} / \mathrm{C})$ is seen in white. Magnifications are indicated by boxes. 
A

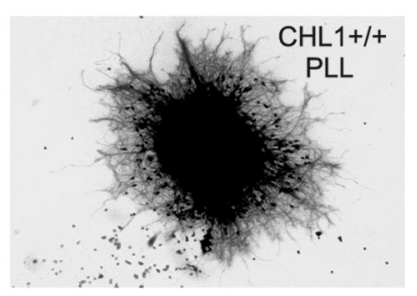

B

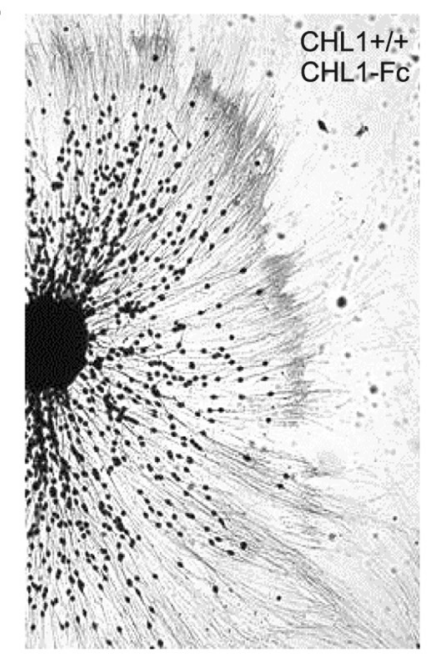

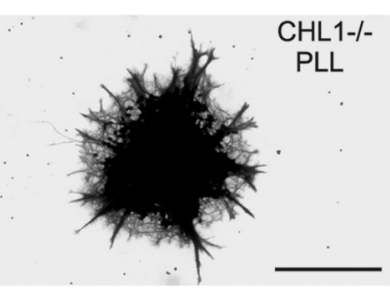

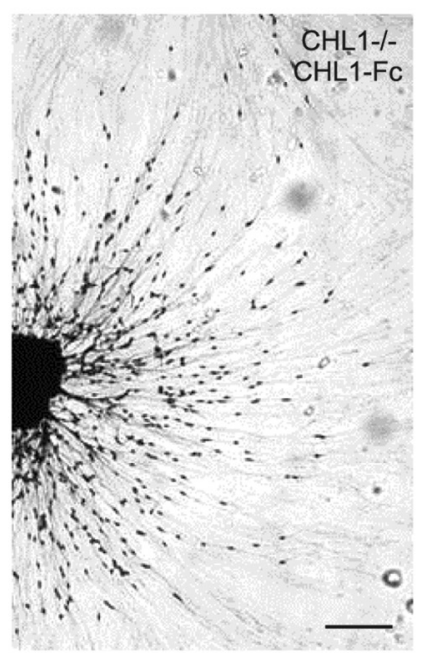

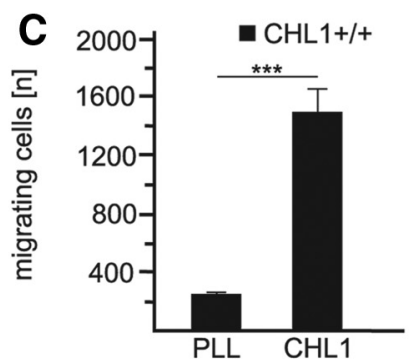
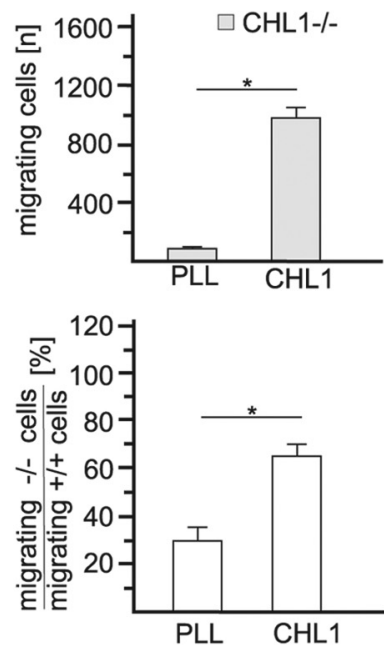
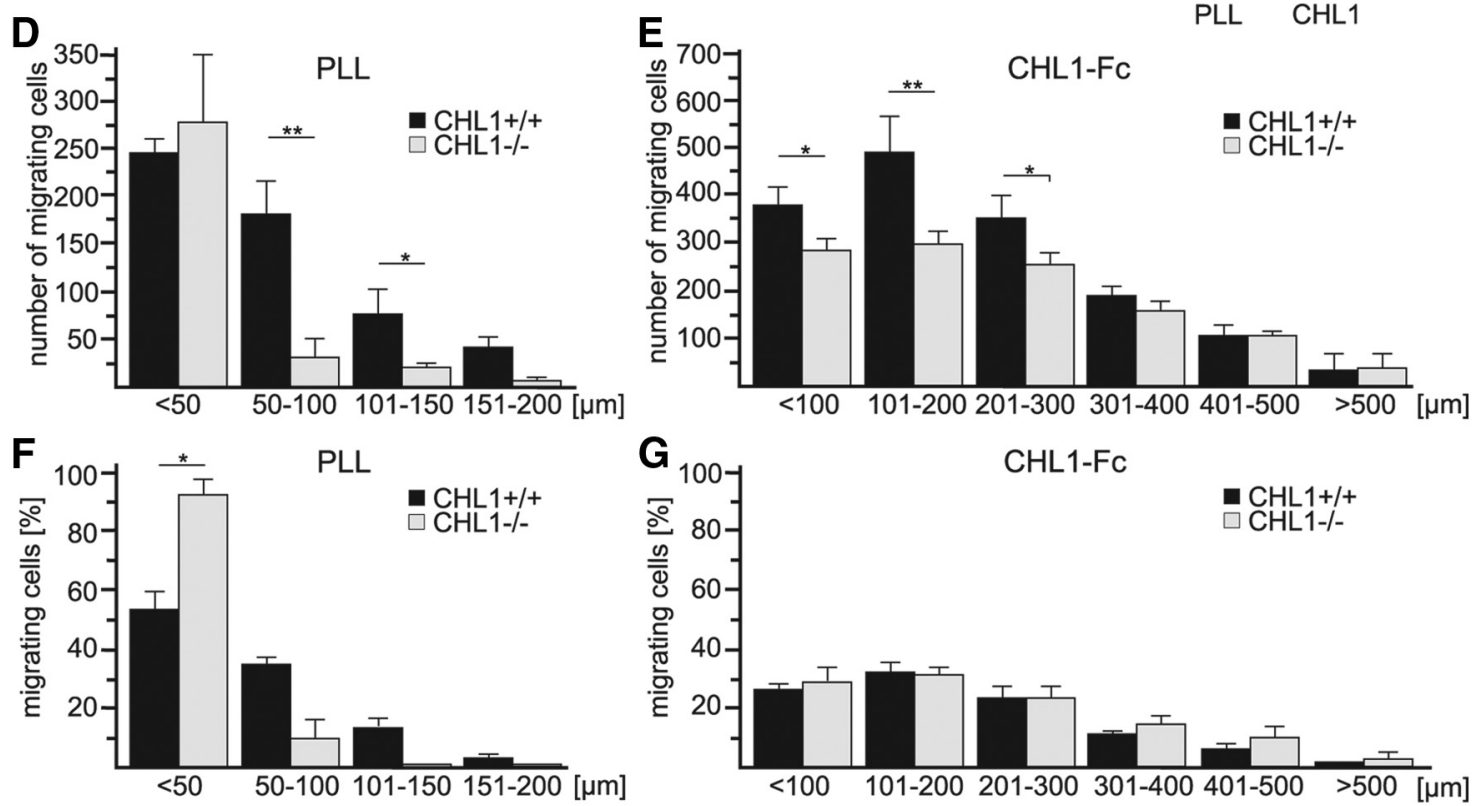

Figure 10. CHL1 stimulates granule cell migration. Cerebellar explants from 6- to 8-d-old wild-type (CHL1 ${ }^{+/+}$) and CHL1-deficient (CHL1 ${ }^{-/-}$) mice were maintained on substrate-coated PLL or CHL1-Fc (CHL1). $A-C$, Representative images of explants $(\boldsymbol{A}, \boldsymbol{B})$, the total numbers of cell bodies migrating out of the explants, and the number of migrating $C H L 1-$ deficient cells relative to the number of migrating wild-type cells are shown ( $\boldsymbol{C}$. $\boldsymbol{D}-\mathbf{G}$, Numbers of cell bodies in distinct distance intervals from the explant border $(\boldsymbol{D}, \boldsymbol{E})$ and the numbers of cells in a distance interval relative to the total number of migrating cells $(\boldsymbol{F}, \boldsymbol{G})$ are shown. $\boldsymbol{C}-\boldsymbol{G}$, Mean values \pm SEM from three independent experiments counting all migrating cells from 10 explants per group in each experiment are shown. The groups were analyzed by two-tailed Student's $t$ test, and significant differences between groups $\left({ }^{*} p<0.01 ;{ }^{* *} p<0.005 ;{ }^{* * *} p<0.001\right)$ are indicated. Scale bars, $100 \mu \mathrm{m}$.

migratory, or is missing at the end of the first postnatal week. Since we did not observe a loss of granule cells in early postnatal cerebella in vivo (Jakovcevski et al., 2009), it is unlikely that a subpopulation of cells is missing. Thus, we favor the view that some cells do not migrate, and represent postmitotic and postmigratory granule cells. Since CHL1 negatively affects neuronal differentiation (Huang et al., 2011), we infer that the ablation of CHL1 leads to enhanced differentiation, precocious maturation, and reduced numbers of migrating cells.
To test this hypothesis, explants from cerebella of 4- to 5-dold wild-type and CHL1-deficient mice were analyzed for granule cell migration on PLL or CHL1-Fc substrates. Similar numbers of wild-type and CHL1-deficient cells migrated out of the explants when maintained on PLL or CHL1-Fc (data not shown), implying that cell migration at this developmental stage is CHL1 independent. Likewise, the total length of neurites extending from the explants was similar under all conditions (data not shown), indicating that neurite outgrowth is also CHL1 independent at this 
early developmental stage. Next, we analyzed differentiation in cultures of dissociated cells from cerebella of 4- to 5-d-old wild-type and CHL1-deficient mice by immunostaining for $\beta$ III-tubulin and determined numbers of undifferentiated $\beta$ III-tubulin-negative cells. Compared with the numbers determined on PLL, the numbers of $\beta$ III-tubulin-negative cells relative to the total cell number was increased when wild-type cerebellar cells were maintained on CHL1-Fc (Fig. 13). On PLL and CHL1-Fc, the numbers of $\beta$ III-tubulin-negative CHL1-deficient cells relative to the total cell number were similar to those observed for wild-type cells on PLL (Fig. 13). This result indicates that a homophilic CHL1 trans-interaction inhibits the differentiation of granule cell precursors at early developmental stages and that their differentiation is enhanced in the absence of this trans-interaction. Of note, similar numbers of $\beta$ III-tubulinpositive cells with neurites and similar neurite lengths were seen under all conditions (data not shown), confirming that neurite outgrowth does not depend on CHL1 during early stages of postnatal cerebellar development.

To investigate whether differentiation, proliferation, and/or migration is affected in CHL1-deficient mice at early cerebellar developmental stages in vivo, sections of cerebella from 3-, 5-, and 7-d-old wildtype, and CHL1-deficient mice were immunostained for Ki67, a marker of proliferating cells; for doublecortin, a marker for migrating cells; for Pax6, a marker for granule cells; and for NeuN, a marker for differentiated neurons. Similar numbers of Ki67-positive cells were observed in the external granular layer of 3-d-old wild-type and CHL1-deficient mice $(n=6$ : $545.08 \pm 24.74$ vs $563.99 \pm 48.61 \times 10^{3}$ cells $\left./ \mathrm{mm}^{-3} ; p<0.75\right)$, whereas the numbers of Ki67-positive cells in the external granular layer were higher in 5-d-old CHL1-deficient mice than in 5-d-old wild-type mice (Fig. 14A). Since we observed no differences in numbers of Ki67-positive cells in the external granular layers of 7-d-old wild-type and CHL1-deficient cerebella (Jakovcevski et al., 2009), the previous and present results show that granule cell proliferation depends on CHL1 during a narrow time window of early postnatal cerebellar development.

Previously, we found an enhanced number of NeuN-positive cells in the molecular $(+45 \%)$ and internal granular layers $(+14 \%)$ of 7 -d-old CHL1-deficient cerebella relative to wildtype cerebella (Jakovcevski et al., 2009). Here, we also observed an increased number of NeuN-positive cells in the molecular and internal granular layers of 7-d-old as well as 5-d-old CHL1deficient cerebella (Fig. 14B), while no differences were detectable in the layers of 3-d-old cerebella (data not shown). No significant differences between the genotypes were found for the numbers of Pax6-positive cells in the external granular, molecular, and internal granular layers of cerebella from 5- and 7-d-old mice (Fig. 14C) as well as 3-d-old mice (data not shown). However, increased or decreased numbers of NeuN and Pax6 double- positive cells were found in the internal layers of 5- or 7-d-old CHL1-deficient cerebella, respectively, relative to the numbers observed in wild-type cerebella (Fig. 14D), while no differences were seen in 3-d-old cerebella (data not shown). These changes in the numbers of differentiated granule cells in cerebella of 5- and 7-d-old CHL1-deficient mice suggest that differentiation at this developmental stage is regulated by CHL1.

The numbers of Pax6 and doublecortin double-positive cells in the external granular layers of cerebella from 5-d-old wild-type and CHL1-deficient mice were similar, while a reduced number was found in the external granular layers of 7-d-old CHL1deficient relative to wild-type cerebella (Fig. 14E). No differences were detected in the external granular layers of cerebella from 3-d-old wild-type and CHL1-deficient mice. This result indicates that the migration of cerebellar granule cells is CHL1 independent at early developmental stages, but CHL1 dependent at later stages.

To analyze whether migration at later stages depends on vitronectin, we determined the number of NeuN-positive cells as well as the number of Pax6 and doublecortin double-positive cells in cerebella of 5- and 7-d-old vitronectin-deficient mice. In addition, we analyzed whether differentiation and/or proliferation is affected in vitronectin-deficient mice at early cerebellar developmental stages by counting Ki67-positive, Pax6-positive, as well as NeuN and Pax6 double-positive cells in cerebella of 5and 7-d-old vitronectin-deficient mice. Increased numbers of 

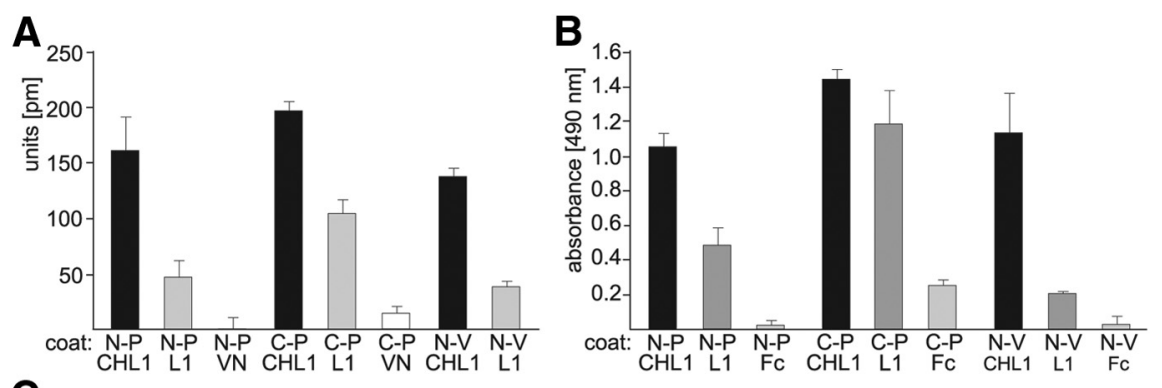

C

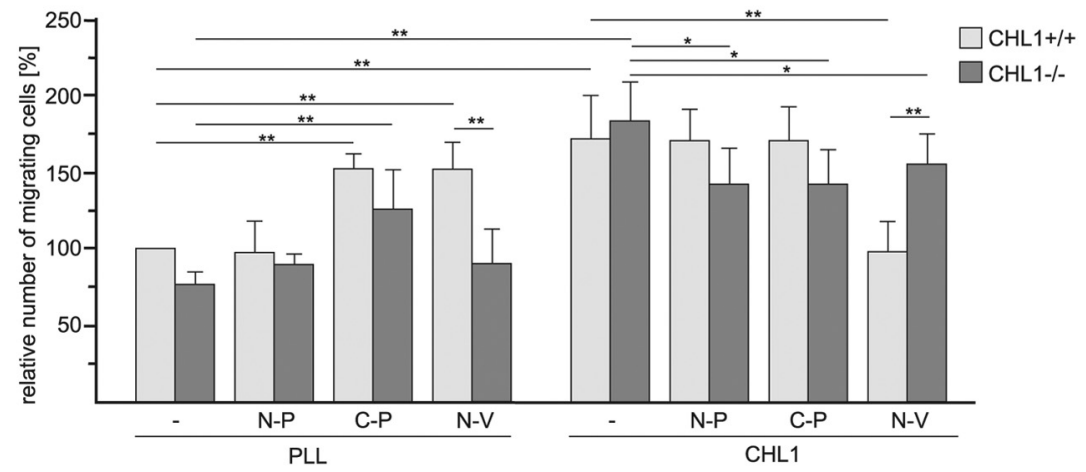

Figure 12. $\quad \mathrm{N}$-terminal vitronectin and PAI-2 parts mediate binding to CHL1 and are involved in CHL1-dependent granule cell migration. $\boldsymbol{A}$, Label-free binding assay using $125 \mathrm{~nm}$ soluble CHL1-Fc, L1-Fc, or vitronectin, and $25 \mathrm{~nm}$ substrate-coated recombinant N-terminal PAI-2 (N-P), C-terminal PAI-2 (C-P), and N-terminal vitronectin (N-V) fragments. Mean values \pm SD of reflected wavelength shifts from three independent experiments performed in triplicate are shown. $\boldsymbol{B}$, ELISA with 25 nm substrate-coated recombinant N-terminal PAl-2 (N-P), C-terminal PAI-2 (C-P), and N-terminal vitronectin (N-V) fragments, and 5 nm soluble CHL1$\mathrm{Fc}$, L1-Fc, or Fc. Mean values \pm SD from three independent experiments performed in triplicate are shown. $C$, Cerebellar explants from 6- to 8-d-old wild-type and CHL1-deficient mice were maintained on substrate-coated PLL or CHL1-Fc (CHL1) in the absence $(-)$ or presence of N-terminal PAI-2 (N-P), C-terminal PAI-2 (C-P), and N-terminal vitronectin (N-V) fragments. The numbers of cell bodies migrating out of the explants were determined, and mean values \pm SEM from three independent experiments, counting all migrating cells from 10 explants per group in each experiment, are shown. The groups were analyzed by two-tailed Student's $t$ test, and significant differences between groups $\left({ }^{* * *} p<0.001\right)$ are indicated.
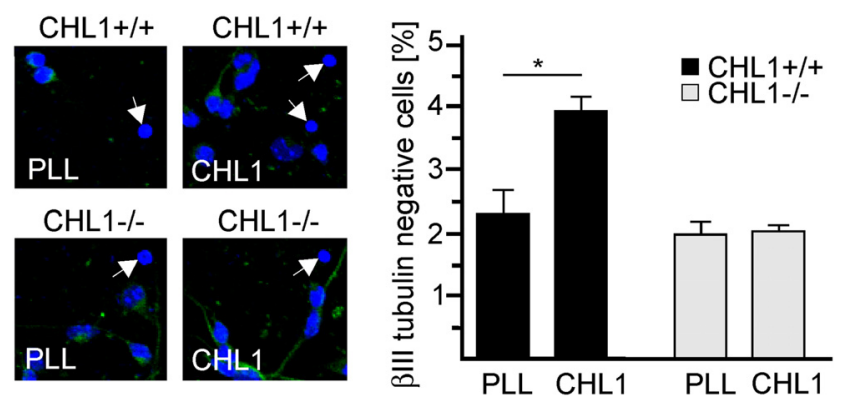

Figure 13. CHL1 regulates neuronal differentiation at early stages of cerebellar development in vitro. Dissociated cells from 4-to 5-d-old wild-type and CHL1-deficient mice were fixed, permeabilized, and stained for $\beta$ III-tubulin. Representative cells are shown, and $\beta$ III-tubulinnegative cells with dark blue round nuclei are indicated by arrows. Mean values \pm SD of the numbers of $\beta$ III-tubulin-negative cells relative to total cell numbers from four independent experiments are shown. The groups were analyzed by two-tailed Student's $t$ test, and significant differences between groups $\left({ }^{*} p<0.01\right)$ are indicated.

Ki67-positive cells were observed in the external granular layer of vitronectin-deficient mice compared with wild-type mice (Fig. $14 A$ ), whereas similar numbers of Ki67-positive cells were observed in the external granular layer of 7-d-old wild-type and vitronectin-deficient mice $\left(n=6 ; 715.28 \pm 74.9\right.$ vs $713.12 \pm 80.5 \times 10^{3}$ cells/mm $\left.{ }^{-3} ; p<1\right)$. These results suggest that, similar to CHL1, vitronectin is involved in the regulation of granule cell proliferation around postnatal day 5. Increased numbers of NeuNpositive cells were observed in the molecular and internal layers of 5- and 7-d-old vitronectin-deficient cerebella (Fig. 14B). The numbers of Pax6-positive cells in the molecular and internal granular layers of cerebella from 5- and 7-d-old vitronectin-deficient mice were similar to those in wild-type mice (Fig. 14C). The numbers were also similar in the external granular layers of 7-d-old cerebella, whereas increased numbers were observed in the external granular layer of cerbella from 5-d-old vitronectindeficient mice (Fig. 14C). Numbers of NeuN and Pax6 double-positive cells found in the internal layers of 5-d-old wildtype and vitronectin-deficient cerebella were similar, while decreased numbers were found in 7-d-old vitronectin-deficient cerebella when compared with the numbers observed in wild-type mice (Fig. $14 D)$. The numbers of Pax6 and doublecortin double-positive cells in the external granular layers of cerebella from 5-d-old wild-type and vitronectindeficient mice were similar, while a reduced number was found in the external granular layers of 7-d-old vitronectindeficient mice when compared with the numbers found in wild-type mice (Fig. $14 E)$.

The similar histological phenotypes of CHL1 - and vitronectin-deficient cerebella indicate that migration and differentiation in the mouse cerebellum depend on CHL1 and vitronectin, and suggest that the interaction between CHL1 and vitronectin regulates the migration of granule cells.

\section{Discussion}

In the present study, we provide evidence that homophilic CHL1 trans-interactions promote the differentiation of cerebellar granule cells at approximately postnatal day 5 in the early proliferative developmental stages of the mouse cerebellum, while heterophilic trans-interactions of CHL1 with vitronectin, integrins, PAI-2, uPA, and UPAR contribute to postproliferative neurite outgrowth and granule cell migration 1-2 d later.

The number of undifferentiated granule cells was increased only when dissociated cells from cerebella of 4- to 5-d-old wildtype mice were cultured on CHL1-Fc substrate, but not on a neutral control substrate, suggesting that homophilic CHL1 trans-interactions inhibit or delay differentiation of granule cell precursors before radial glia-guided outside-in migration starts. Increased numbers of differentiated granule neurons in 5-d-old CHL1-deficient cerebella versus wild-type cerebella infer that homophilic CHL1 trans-interactions delay the differentiation of granule cell precursors. Neurite outgrowth and migration from dissociated cerebellar cells and explants of 4- to 5-d-old wild-type and CHL1-deficient mice are similar and are not affected by CHL1-Fc, indicating that neither homophilic nor heterophilic CHL1 trans-interactions affect neuritogenesis or neuronal cell migration in early development. CHL1 is present on parallel fiber axons in the developing molecular layer (Figs. 6, 7; Jakovcevski et al., 2009), and it is thus conceivable that the differentiation of CHL1-expressing postmitotic granule cells is delayed by their 

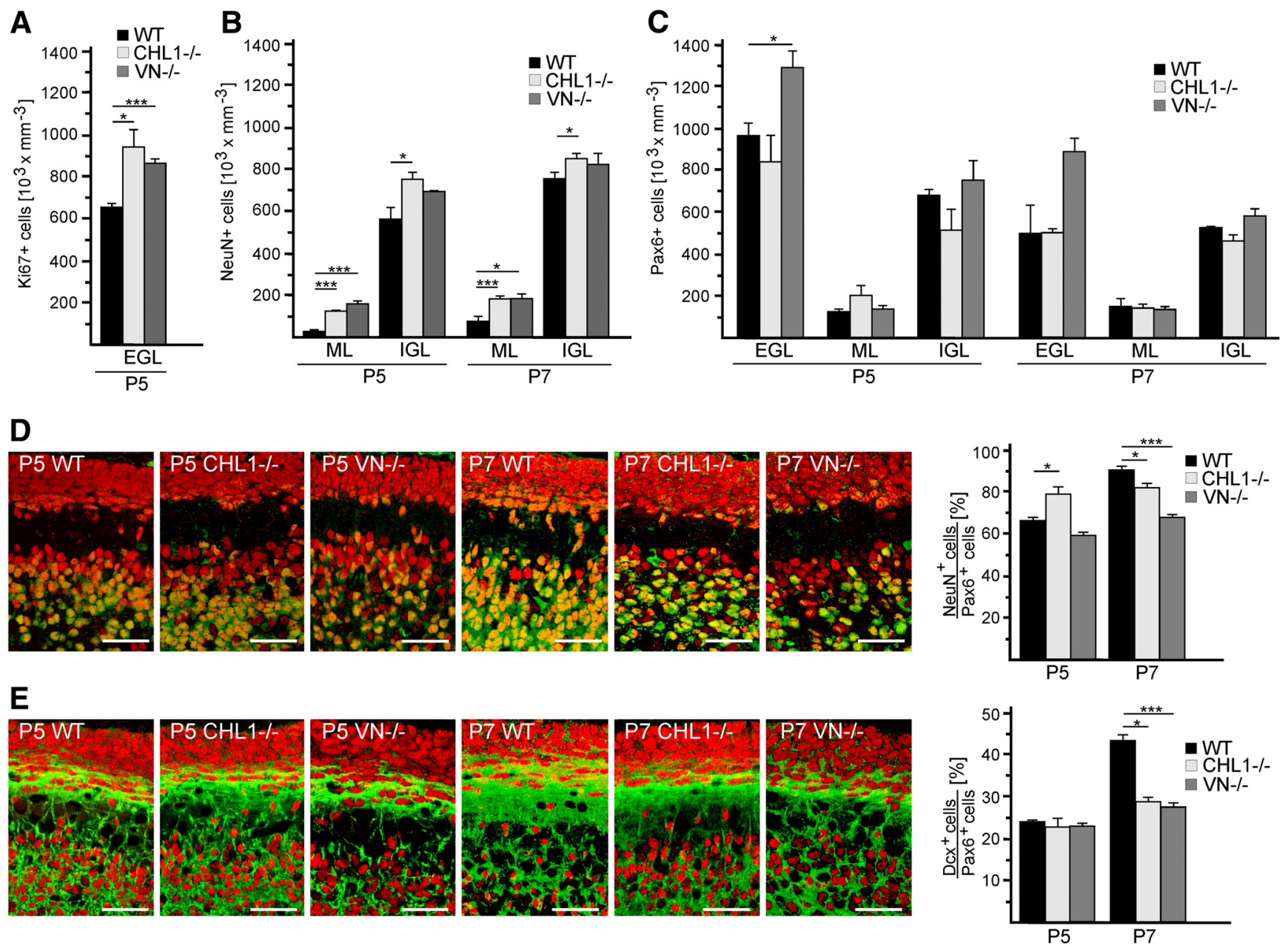

Figure 14. CHL1 regulates neuronal differentiation and migration at early stages of cerebellar development in vivo. A-E, Sections of cerebella from postnatal day 5 or 7 (P5; P7) wild-type (WT) and CHL1-deficient (CHL1 ${ }^{-1-}$ ) or vitronectin-deficient $\left(\mathrm{VN}^{-1-}\right.$ ) mice were immunostained for Ki67 (A), NeuN (B), Pax6 (C), NeuN (green), and Pax6 (red; $\left.\boldsymbol{D}\right)$; and doublecortin (Dcx; green) and Pax6 (red; $\boldsymbol{E})$. $\boldsymbol{A}$, Mean values \pm SEM of Ki67-positive cells per area in the external granular layer (EGL) of cerebella from 5-d-old wild-type mice $(n=8)$, $C H L 1$-deficient mice $(n=8)$, and vitronectin-deficient mice $(n=5)$ are shown. $B, C$, Mean values \pm SEM of NeuN- or Pax6-positive cells per area in the external granular layer, the molecular layer (ML), or the internal granular layer (IGL) of cerebella from 5- and 7-d-old wild-type mice $(n=6)$, CHL1-deficient $(n=6)$, and vitronectin-deficient $(n=5)$ mice are shown. $\boldsymbol{D}, \boldsymbol{E}$, Representative immunofluorescence images and mean values \pm SEM of relative numbers of NeuN/Pax6 double-positive cells (yellow and orange) in the internal granular layer (D) or doublecortin/Pax6 double-positive cells (yellow) in the inner part of the external granular layer $(\boldsymbol{E})$ of cerebella from 5 - and 7-d-old wild-type mice $(n=6)$, CHL1-deficient mice $(n=6)$, and vitronectin-deficient mice $(n=5)$ are shown. $\boldsymbol{A}$ - $\boldsymbol{C}$, The groups were analyzed by two-tailed Student's $t$ test, and significant differences between groups ( ${ }^{*} p<0.01 ;{ }^{* *} p<0.001$ ) are indicated. Scale bars, $20 \mu \mathrm{m}$.

homophilic CHL1 trans-interactions with CHL1-positive parallel fibers. Since clonally related granule cells develop within a distinct time window and stack their axons in chronological order from deep to superficial sublayers (Espinosa and Luo, 2008), CHL1 likely regulates the staggered organization of the molecular layer. Of note, axons of granule cells in deep and superficial sublayers form synaptic contacts predominantly with basket and stellate cells, respectively (Lemkey-Johnston and Larramendi, 1968), and CHL1 ablation causes aberrant branching and orientation of stellate cell, but not basket cell, axons (Ango et al., 2008).

Cells from 6- to 8-d-old mice of both genotypes showed CHL1-Fc enhanced migration and neuritogenesis, indicating that heterophilic trans-interactions regulate migration and neuritogenesis at later stages when granule cell bodies initiate migration along radial Bergmann glial processes. Since Bergmann glial processes start expressing CHL1 at approximately postnatal day 7 (Ango et al., 2008; Jakovcevski et al., 2009), interactions of CHL1 on Bergmann glial processes with its binding partners on leading processes and on cell bodies of granule cells may stimulate the migration of granule cells to the internal granular layer. The re- ceptors for CHL1 on the migrating granule cell neurons are unknown, but may involve the newly identified CHL1 interaction partners of the present study.

Postmitotic extension of granule cell axons precedes migration of their cell bodies, and we propose that this extension relies on the heterophilic trans-interaction of CHL1 on Bergmann glia with binding partners on parallel fibers. Bergmann glial processes serve as scaffold for the extension of stellate cell axons and interact with Purkinje cell dendrites (Ango et al., 2008). Interestingly, the numbers of NeuN-positive granule cells in the molecular layer are increased in 5- and 7-day-old CHL1-deficient mice, suggesting that the lack of heterophilic CHL1 trans-interactions impairs neuronal migration and results in an accumulation of granule cells in the molecular layer. The numbers of NeuNpositive granule cell neurons in the internal granular layer are increased in 5- and 7-d-old CHL1-deficient mice, while the numbers of NeuN/Pax6 double-positive granule neurons in the internal granular layer are increased in 5-d-old CHL1-deficient cerebella, but decreased in 7-d-old CHL1-deficient cerebella. Ablation of CHL1 causes precocious differentiation of granule cell 
precursors before migration, enhances migration of premature granule cells into the internal granular layer, and may lead to increased numbers of NeuN-positive differentiated granule cells in this layer in CHL1-deficient mice at postnatal day 7. Since Pax6 levels in granule neurons decrease after outside-in migration into the internal granular layer (Yamasaki et al., 2001; Mathisen et al., 2013), granule cells in the internal granular layer of CHL1deficient cerebella are likely Pax6 negative at postnatal day 7 . Reduction in the numbers of Pax6/NeuN double-positive cells in the internal granular layer of 7-d-old CHL1-deficient mice may be due to premature development of granule cells. These cells are prematurely differentiated postmigratory granule neurons and may represent a subpopulation of CHL1-deficient granule cells, which do not migrate from cerebellar explants of 7-d-old CHL1deficient mice (present study) and which are eliminated at 2 months of age (Jakovcevski et al., 2009).

Vitronectin and PAI-2 bind to CHL1 and colocalize with CHL1 on migrating granule cells. The migration of granule cells along Bergmann glial processes and the extension of their parallel fiber axons involve heterophilic CHL1 interactions with vitronectin, and with the vitronectin receptors $\alpha \mathrm{v} \beta 1$ and $\alpha \mathrm{v} \beta 3$ integrins. Previous studies had shown that $\beta 1$ integrin is expressed by migrating granule cells (Blaess et al., 2004), that vitronectin and CHL1 are located on parallel fibers (Murase and Hayashi, 1998; Jakovcevski et al., 2009), and that $\alpha \mathrm{v} \beta 3$ is expressed in the inner granular layer (Pons et al., 2001). Here, we show that granule cell migration depends on heterophilic trans-interactions of CHL1 with PAI-2, and integrins $\alpha 3 \beta 1, \alpha 2 \beta 1$, and $\alpha 1 \beta 1$, suggesting that cross talk among integrins, vitronectin, and PAI-2 underlies CHL1-mediated migration. In contrast, laminin receptors containing $\alpha 6$ or $\alpha 7$ integrin subunits, expressed by proliferating granule cell precursors (Pons et al., 2001), are not involved in CHL1-triggered migration. The similar histological phenotypes of cerebella from 7-d-old CHL1- and vitronectin-deficient mice showing an accumulation of migrating granule cells in the molecular layer underscore the importance of CHL1 and vitronectin for granule cell migration. Notably, these results suggest that the interaction between CHL1 and vitronectin is required for outside-in migration of granule cells.

Migration also depends on CHL1-induced signaling via uPA/ uPAR. Interactions of the glycosylphosphatidylinositol-anchored signaling receptor uPAR with its signaling coreceptors (e.g., $\alpha 3 \beta 1$ and $\alpha \mathrm{v} \beta 3$ integrins), and with its ligands uPA and vitronectin, trigger signaling pathways and also promote non-neural cell migration (Madsen et al., 2007). These signaling pathways might be modulated by the interaction of CHL1 with PAI-2, vitronectin, and integrins. Since we observed that CHL1, but not vitronectin, binds to PAI-2 fragments in the label-free binding assay, we propose that the binding of CHL1 to PAI-2 shifts the PAI-2 protein into a conformation that allows binding of PAI-2 to vitronectin (Lobov et al., 2004). Binding of CHL1 to PAI-2 and CHL1induced binding of PAI-2 to vitronectin may affect not only the PAI-2/uPA and vitronectin/uPA/uPAR interactions (Smith and Marshall, 2010), but also the PAI-2-dependent effects on cell adhesion and migration (Lobov and Ranson, 2011).

The expression of PAI-2 and UPA increases upon excitotoxic kainate treatment, leading to epileptic seizures (Masos and Miskin, 1997; Sharon et al., 2002; Iyer et al., 2010; Cho et al., 2012). The expression of PAI-2 is upregulated in response to synaptic activity and is neuroprotective under stress conditions (Zhang et al., 2009). Stress, injury, and inflammation induce uPAR expression; and UPAR-deficient mice exhibit reduced damage upon ischemia, a reduced number of GABAergic interneurons, in- creased sensitivity to pharmacologically induced seizures, enhanced anxiety, and atypical social behavior. These findings indicate that these molecules influence essential brain functions (Powell et al., 2003; Levitt, 2005; Nagai et al., 2008; RoyerZemmour et al., 2008; Archinti et al., 2011; Ndode-Ekane and Pitkänen, 2013).

In humans, uPAR, similar to CHL1, is linked to epilepsy and autism spectrum/cognitive disorders (Campbell et al., 2008; Lahtinen et al., 2009; Eagleson et al., 2010; Liu et al., 2010; Bruneau and Szepetowski, 2011), suggesting an involvement of PAI-2, uPA, and UPAR in synaptic plasticity under physiological conditions and in neuropathological disorders. Since CHL1 is also involved in synaptic plasticity and behavior, we propose that CHL1-induced cellular responses underlying synaptic plasticity are triggered-at least partially-by CHL1 interaction with PAI-2, mediated via uPA/uPAR-dependent signaling, which depends not only on integrins but also on vitronectin. Our observations draw attention to the fact that the functions of novel receptors for Ig superfamily cell adhesion molecules are closely linked to decisive morphogenetic events in diverse activities during development, synaptic plasticity, and regeneration. These changes in cooperating molecules occur in a short time window of only several days of major morphogenetic changes during cerebellar development.

\section{References}

Andreyeva A, Leshchyns'ka I, Knepper M, Betzel C, Redecke L, Sytnyk V, Schachner M (2010) CHL1 is a selective organizer of the presynaptic machinery chaperoning the SNARE complex. PLoS One 5:e12018. CrossRef Medline

Angeloni D, Lindor NM, Pack S, Latif F, Wei MH, Lerman MI (1999a) CALL gene is haploinsufficient in a $3 p$ - syndrome patient. Am J Med Genet 86:482-485. CrossRef Medline

Angeloni D, Wei MH, Lerman MI (1999b) Two single nucleotide polymorphisms (SNPs) in the CALL gene for association studies with IQ. Psychiatr Genet 9:165-167. CrossRef Medline

Ango F, Wu C, Van der Want JJ, Wu P, Schachner M, Huang ZJ (2008) Bergmann glia and the recognition molecule CHL1 organize GABAergic axons and direct innervation of Purkinje cell dendrites. PLoS Biol 6:e103. CrossRef Medline

Archinti M, Britto M, Eden G, Furlan F, Murphy R, Degryse B (2011) The urokinase receptor in the central nervous system. CNS Neurol Disord Drug Targets 10:271-294. CrossRef Medline

Bae HB, Tadie JM, Jiang S, Park DW, Bell CP, Thompson LC, Peterson CB, Thannickal VJ, Abraham E, Zmijewski JW (2013) Vitronectin inhibits efferocytosis through interactions with apoptotic cells as well as with macrophages. J Immunol 190:2273-2281. CrossRef Medline

Blaess S, Graus-Porta D, Belvindrah R, Radakovits R, Pons S, LittlewoodEvans A, Senften M, Guo H, Li Y, Miner JH, Reichardt LF, Müller U (2004) Beta1-integrins are critical for cerebellar granule cell precursor proliferation. J Neurosci 24:3402-3412. CrossRef Medline

Bodary SC, McLean JW (1990) The integrin beta 1 subunit associates with the vitronectin receptor alpha $\mathrm{v}$ subunit to form a novel vitronectin receptor in a human embryonic kidney cell line. J Biol Chem 265:59385941. Medline

Bolte S, Cordelières FP (2006) A guided tour into subcellular colocalization analysis in light microscopy. J Microsc 224:213-232. CrossRef Medline

Bruneau N, Szepetowski P (2011) The role of the urokinase receptor in epilepsy, in disorders of language, cognition, communication and behavior, and in the central nervous system. Curr Pharm Des 17:1914-1923. CrossRef Medline

Buhusi M, Midkiff BR, Gates AM, Richter M, Schachner M, Maness PF (2003) Close homolog of L1 is an enhancer of integrin-mediated cell migration. J Biol Chem 278:25024-25031. CrossRef Medline

Campbell DB, Li C, Sutcliffe JS, Persico AM, Levitt P (2008) Genetic evidence implicating multiple genes in the MET receptor tyrosine kinase pathway in autism spectrum disorder. Autism Res 1:159-168. CrossRef Medline

Chen QY, Chen Q, Feng GY, Lindpaintner K, Chen Y, Sun X, Chen Z, Gao Z, 
Tang J, He L (2005) Case-control association study of the close homologue of L1 (CHL1) gene and schizophrenia in the Chinese population. Schizophr Res 73:269-274. CrossRef Medline

Chen S, Mantei N, Dong L, Schachner M (1999) Prevention of neuronal cell death by neural adhesion molecules L1 and CHL1. J Neurobiol 38:428439. CrossRef Medline

Cho E, Lee KJ, Seo JW, Byun CJ, Chung SJ, Suh DC, Carmeliet P, Koh JY, Kim JS, Lee JY (2012) Neuroprotection by urokinase plasminogen activator in the hippocampus. Neurobiol Dis 46:215-224. CrossRef Medline

Chu TT, Liu Y (2010) An integrated genomic analysis of gene-function correlation on schizophrenia susceptibility genes. J Hum Genet 55:285-292. CrossRef Medline

Cuoco C, Ronchetto P, Gimelli S, Béna F, Divizia MT, Lerone M, MirabelliBadenier M, Mascaretti M, Gimelli G (2011) Microarray based analysis of an inherited terminal 3p26.3 deletion, containing only the CHL1 gene, from a normal father to his two affected children. Orphanet J Rare Dis 6:12. CrossRef Medline

Dahme M, Bartsch U, Martini R, Anliker B, Schachner M, Mantei N (1997) Disruption of the mouse L1 gene leads to malformations of the nervous system. Nat Genet 17:346-349. CrossRef Medline

Demyanenko GP, Schachner M, Anton E, Schmid R, Feng G, Sanes J, Maness PF (2004) Close homolog of L1 modulates area-specific neuronal positioning and dendrite orientation in the cerebral cortex. Neuron 44:423437. CrossRef Medline

Demyanenko GP, Siesser PF, Wright AG, Brennaman LH, Bartsch U, Schachner M, Maness PF (2011) L1 and CHL1 cooperate in thalamocortical axon targeting. Cereb Cortex 21:401-412. CrossRef Medline

Eagleson KL, Gravielle MC, Schlueter McFadyen-Ketchum LJ, Russek SJ, Farb DH, Levitt P (2010) Genetic disruption of the autism spectrum disorder risk gene PLAUR induces GABAA receptor subunit changes. Neuroscience 168:797-810. CrossRef Medline

Espinosa JS, Luo L (2008) Timing neurogenesis and differentiation: insights from quantitative clonal analyses of cerebellar granule cells. J Neurosci 28:2301-2312. CrossRef Medline

Frints SG, Marynen P, Hartmann D, Fryns JP, Steyaert J, Schachner M, Rolf B, Craessaerts K, Snellinx A, Hollanders K, D’Hooge R, De Deyn PP, Froyen G (2003) CALL interrupted in a patient with non-specific mental retardation: gene dosage-dependent alteration of murine brain development and behavior. Hum Mol Genet 12:1463-1474. CrossRef Medline

Hillenbrand R, Molthagen M, Montag D, Schachner M (1999) The close homologue of the neural adhesion molecule L1 (CHL1): patterns of expression and promotion of neurite outgrowth by heterophilic interactions. Eur J Neurosci 11:813-826. CrossRef Medline

Holm J, Hillenbrand R, Steuber V, Bartsch U, Moos M, Lübbert H, Montag D, Schachner M (1996) Structural features of a close homologue of L1 (CHL1) in the mouse: a new member of the L1 family of neural recognition molecules. Eur J Neurosci 8:1613-1629. CrossRef Medline

Horton MA (1997) The alpha v beta 3 integrin "vitronectin receptor." Int J Biochem Cell Biol 29:721-725. CrossRef Medline

Huang X, Zhu LL, Zhao T, Wu LY, Wu KW, Schachner M, Xiao ZC, Fan M (2011) CHL1 negatively regulates the proliferation and neuronal differentiation of neural progenitor cells through activation of the ERK1/2 MAPK pathway. Mol Cell Neurosci 46:296-307. CrossRef Medline

Irintchev A, Koch M, Needham LK, Maness P, Schachner M (2004) Impairment of sensorimotor gating in micse deficient in the cell adhesion molecule L1 or its close homologue, CHL1. Brain Res 1029:131-134. CrossRef Medline

Iyer AM, Zurolo E, Boer K, Baayen JC, Giangaspero F, Arcella A, Di Gennaro GC, Esposito V, Spliet WG, van Rijen PC, Troost D, Gorter JA, Aronica E (2010) Tissue plasminogen activator and urokinase plasminogen activator in human epileptogenic pathologies. Neuroscience 167:929-945. CrossRef Medline

Jakovcevski I, Wu J, Karl N, Leshchyns'ka I, Sytnyk V, Chen J, Irintchev A, Schachner M (2007) Glial scar expression of CHL1, the close homolog of the adhesion molecule L1, limits recovery after spinal cord injury. J Neurosci 27:7222-7233. CrossRef Medline

Jakovcevski I, Siering J, Hargus G, Karl N, Hoelters L, Djogo N, Yin S, Zecevic N, Schachner M, Irintchev A (2009) Close homologue of adhesion molecule L1 promotes survival of Purkinje and granule cells and granule cell migration during murine cerebellar development. J Comp Neurol 513: 496-510. CrossRef Medline

Kalus I, Schnegelsberg B, Seidah NG, Kleene R, Schachner M (2003) The proprotein convertase PC5A and a metalloprotease are involved in the proteolytic processing of the neural adhesion molecule L1. J Biol Chem 278:10381-10388. CrossRef Medline

Kleene R, Loers G, Langer J, Frobert Y, Buck F, Schachner M (2007) Prion protein regulates glutamate-dependent lactate transport of astrocytes. J Neurosci 27:12331-12340. CrossRef Medline

Kolata S, Wu J, Light K, Schachner M, Matzel LD (2008) Impaired working memory duration but normal learning abilities found in mice that are conditionally deficient in the close homolog of L1. J Neurosci 28:1350513510. CrossRef Medline

Lahtinen L, Huusko N, Myöhänen H, Lehtivarjo AK, Pellinen R, Turunen MP, Ylä-Herttuala S, Pirinen E, Pitkänen A (2009) Expression of urokinase-type plasminogen activator receptor is increased during epileptogenesis in the rat hippocampus. Neuroscience 163:316-328. CrossRef Medline

Lemkey-Johnston N, Larramendi LM (1968) Types and distribution of synapses upon basket and stellate cells of the mouse cerebellum: an electron microscopic study. J Comp Neurol 134:73-112. CrossRef Medline

Leshchyns'ka I, Sytnyk V, Richter M, Andreyeva A, Puchkov D, Schachner M (2006) The adhesion molecule CHL1 regulates uncoating of clathrincoated synaptic vesicles. Neuron 52:1011-1025. CrossRef Medline

Levitt P (2005) Disruption of interneuron development. Epilepsia 46 [Suppl 7]:22-28. CrossRef Medline

Liu B, Zhang B, Wang T, Liang QC, Jing XR, Zheng J, Wang C, Meng Q, Wang L, Wang W, Guo H, You Y, Zhang H, Gao GD (2010) Increased expression of urokinase-type plasminogen activator receptor in the frontal cortex of patients with intractable frontal lobe epilepsy. J Neurosci Res 88 : 2747-2754. CrossRef Medline

Lobov S, Ranson M (2011) Molecular competition between plasminogen activator inhibitors type -1 and -2 for urokinase: implications for cellular proteolysis and adhesion in cancer. Cancer Lett 303:118-127. CrossRef Medline

Lobov S, Wilczynska M, Bergström F, Johansson LB, Ny T (2004) Structural bases of the redox-dependent conformational switch in the serpin PAI-2. J Mol Biol 344:1359-1368. CrossRef Medline

Loers G, Schachner M (2007) Recognition molecules and neural repair. J Neurochem 101:865-882. CrossRef Medline

Loers G, Makhina T, Bork U, Dörner A, Schachner M, Kleene R (2012) The interaction between cell adhesion molecule L1, matrix metalloproteinase 14 , and adenine nucleotide translocator at the plasma membrane regulates L1-mediated neurite outgrowth of murine cerebellar neurons. J Neurosci 32:3917-3930. CrossRef Medline

Madsen CD, Ferraris GM, Andolfo A, Cunningham O, Sidenius N (2007) uPAR-induced cell adhesion and migration: vitronectin provides the key. J Cell Biol 177:927-939. CrossRef Medline

Makhina T, Loers G, Schulze C, Ueberle B, Schachner M, Kleene R (2009) Extracellular GAPDH binds to L1 and enhances neurite outgrowth. Mol Cell Neurosci 41:206-218. CrossRef Medline

Maness PF, Schachner M (2007) Neural recognition molecules of the immunoglobulin superfamily: signaling transducers of axon guidance and neuronal migration. Nat Neurosci 10:19-26. CrossRef Medline

Masos T, Miskin R (1997) mRNAs encoding urokinase-type plasminogen activator and plasminogen activator inhibitor- 1 are elevated in the mouse brain following kainate-mediated excitation. Brain Res Mol Brain Res 47:157-169. CrossRef Medline

Mathisen GH, Yazdani M, Rakkestad KE, Aden PK, Bodin J, Samuelsen M, Nygaard UC, Goverud IL, Gaarder M, Løberg EM, Bølling AK, Becher R, Paulsen RE (2013) Prenatal exposure to bisphenol A interferes with the development of cerebellar granule neurons in mice and chicken. Int J Dev Neurosci 31:762-769. CrossRef Medline

Montag-Sallaz M, Schachner M, Montag D (2002) Misguided axonal projections, neural cell adhesion molecule 180 mRNA upregulation, and altered behavior in mice deficient for the close homolog of L1. Mol Cell Biol 22:7967-7981. CrossRef Medline

Morag A, Pasmanik-Chor M, Oron-Karni V, Rehavi M, Stingl JC, Gurwitz D (2011) Genome-wide expression profiling of human lymphoblastoid cell lines identifies CHL1 as a putative SSRI antidepressant response biomarker. Pharmacogenomics 12:171-184. CrossRef Medline

Morellini F, Lepsveridze E, Kähler B, Dityatev A, Schachner M (2007) Reduced reactivity to novelty, impaired social behavior, and enhanced basal synaptic excitatory activity in perforant path projections to the dentate 
gyrus in young adult mice deficient in the neural cell adhesion molecule CHL1. Mol Cell Neurosci 34:121-136. CrossRef Medline

Murase S, Hayashi Y (1998) Concomitant expression of genes encoding integrin alpha $\mathrm{v}$ beta 5 heterodimer and vitronectin in growing parallel fibers of postnatal rat cerebellum: a possible role as mediators of parallel fiber elongation. J Comp Neurol 397:199-212. Medline

Nagai N, Okada K, Kawao N, Ishida C, Ueshima S, Collen D, Matsuo O (2008) Urokinase-type plasminogen activator receptor (uPAR) augments brain damage in a murine model of ischemic stroke. Neurosci Lett 432:46-49. CrossRef Medline

Ndode-Ekane XE, Pitkänen A (2013) Urokinase-type plasminogen activator receptor modulates epileptogenesis in mouse model of temporal lobe epilepsy. Mol Neurobiol 47:914-937. CrossRef Medline

Nikonenko AG, Sun M, Lepsveridze E, Apostolova I, Petrova I, Irintchev A, Dityatev A, Schachner M (2006) Enhanced perisomatic inhibition and impaired long-term potentiation in the CA1 region of juvenile CHL1deficient mice. Eur J Neurosci 23:1839-1852. CrossRef Medline

Pons S, Trejo JL, Martínez-Morales JR, Martí E (2001) Vitronectin regulates Sonic hedgehog activity during cerebellum development through CREB phosphorylation. Development 128:1481-1492. Medline

Powell EM, Campbell DB, Stanwood GD, Davis C, Noebels JL, Levitt P (2003) Genetic disruption of cortical interneuron development causes region- and GABA cell type-specific deficits, epilepsy, and behavioral dysfunction. J Neurosci 23:622-631. Medline

Pratte M, Jamon M (2009) Impairment of novelty detection in mice targeted for the Chl1 gene. Physiol Behav 97:394-400. CrossRef Medline

Pratte M, Rougon G, Schachner M, Jamon M (2003) Mice deficient for the close homologue of the neural adhesion cell L1 (CHL1) display alterations in emotional reactivity and motor coordination. Behav Brain Res 147:3139. CrossRef Medline

Preissner KT, Reuning U (2011) Vitronectin in vascular context: facets of a multitalented matricellular protein. Semin Thromb Hemost 37:408-424. CrossRef Medline

Preissner KT, Wassmuth R, Müller-Berghaus G (1985) Physicochemical characterization of human S-protein and its function in the blood coagulation system. Biochem J 231:349-355. Medline

Preissner KT, Holzhüter S, Justus C, Müller-Berghaus G (1989) Identification of and partial characterization of platelet vitronectin: evidence for complex formation with platelet-derived plasminogen activator inhibitor-1. Blood 74: 1989-1996. Medline

Rolf B, Lang D, Hillenbrand R, Richter M, Schachner M, Bartsch U (2003) Altered expression of CHL1 by glial cells in response to optic nerve injury and intravitreal application of fibroblast growth factor-2. J Neurosci Res 71:835-843. CrossRef Medline

Royer-Zemmour B, Ponsole-Lenfant M, Gara H, Roll P, Lévêque C, Massacrier A, Ferracci G, Cillario J, Robaglia-Schlupp A, Vincentelli R, Cau P, Szepetowski P (2008) Epileptic and developmental disorders of the speech cortex: ligand/receptor interaction of wild-type and mutant SRPX2 with the plasminogen activator receptor uPAR. Hum Mol Genet 17:3617-3630. CrossRef Medline
Sakurai K, Migita O, Toru M, Arinami T (2002) An association between a missense polymorphism in the close homologue of L1 (CHL1, CALL) gene and schizophrenia. Mol Psychiatry 7:412-415. CrossRef Medline

Salyakina D, Cukier HN, Lee JM, Sacharow S, Nations LD, Ma D, Jaworski JM, Konidari I, Whitehead PL, Wright HH, Abramson RK, Williams SM, Menon R, Haines JL, Gilbert JR, Cuccaro ML, Pericak-Vance MA (2011) Copy number variants in extended autism spectrum disorder families reveal candidates potentially involved in autism risk. PLoS One 6:e26049. CrossRef Medline

Schmidt C, Lepsverdize E, Chi SL, Das AM, Pizzo SV, Dityatev A, Schachner M (2008) Amyloid precursor protein and amyloid beta-peptide bind to ATP synthase and regulate its activity at the surface of neural cells. Mol Psychiatry 13:953-969. CrossRef Medline

Sharon R, Abramovitz R, Miskin R (2002) Plasminogen mRNA induction in the mouse brain after kainate excitation: codistribution with plasminogen activator inhibitor-2 (PAI-2) mRNA. Brain Res Mol Brain Res 104: 170-175. CrossRef Medline

Shoukier M, Fuchs S, Schwaibold E, Lingen M, Gärtner J, Brockmann K, Zirn B (2013) Microduplication of 3p26.3 in nonsyndromic intellectual disability indicates an important role of CHL1 for normal cognitive function. Neuropediatrics 44:268-271 CrossRef Medline

Smith HW, Marshall CJ (2010) Regulation of cell signaling by uPAR. Nat Rev Mol Cell Biol 11:23-36. CrossRef Medline

Tam GW, van de Lagemaat LN, Redon R, Strathdee KE, Croning MD, Malloy MP, Muir WJ, Pickard BS, Deary IJ, Blackwood DH, Carter NP, Grant SG (2010) Confirmed rare copy number variants implicate novel genes in schizophrenia. Biochem Soc Trans 38:445-451. CrossRef Medline

Wang S, Cesca F, Loers G, Schweizer M, Buck F, Benfenati F, Schachner M, Kleene R (2011) Synapsin I is an oligomannose-carrying glycoprotein, acts as an oligomannose-binding lectin, and promotes neurite outgrowth and neuronal survival when released via glia-derived exosomes. J Neurosci 31:7275-7290. CrossRef Medline

Wei Y, Eble JA, Wang Z, Kreidberg JA, Chapman HA (2001) Urokinase receptors promote betal integrin function through interactions with integrin alpha3beta1. Mol Biol Cell 12:2975-2986. CrossRef Medline

Wright AG, Demyanenko GP, Powell A, Schachner M, Enriquez-Barreto L, Tran TS, Polleux F, Maness PF (2007) Close homolog of L1 and neuropilin 1 mediate guidance of thalamocortical axons at the ventral telencephalon. J Neurosci 27:13667-13679. CrossRef Medline

Yamasaki T, Kawaji K, Ono K, Bito H, Hirano T, Osumi N, Kengaku M (2001) Pax6 regulates granule cell polarization during parallel fiber formation in the developing cerebellum. Development 128:3133-3144. Medline

Zhang SJ, Zou M, Lu L, Lau D, Ditzel DA, Delucinge-Vivier C, Aso Y, Descombes P, Bading H (2009) Nuclear calcium signaling controls expression of a large gene pool: identification of a gene program for acquired neuroprotection induced by synaptic activity. PLoS Genet 5:e1000604. CrossRef Medline 